\title{
INTEGRATION OF SECURITIES MARKET INFRASTRUCTURES IN \\ THE EURO AREA
}

by Heiko Schmiedel

and Andreas Schönenberger 
EUROPEAN CENTRAL BANK

\section{OCCASIONAL PAPER SERIES} N0. 33 I JULY 2005

\section{INTEGRATION OF SECURITIES MARKET INFRASTRUCTURES IN THE EURO AREA}

by Heiko Schmiedel and Andreas Schönenberger

\section{EURO}

This paper can be downloaded without charge from the ECB's website (http://www.ecb.int) or from the Social Science Research Network electronic library at http://ssrn.com/abstract_id=752093. 
(ㄷ) European Central Bank, 2005

\section{Address}

Kaiserstrasse 29

60311 Frankfurt am Main

Germany

Postal address

Postfach 160319

60066 Frankfurt am Main

Germany

Telephone

+496913440

Website

http://www.ecb.int

Fax

+496913446000

Telex

$411144 \mathrm{ecb} d$

All rights reserved. Reproduction for educational and non-commercial purposes is permitted provided that the source is acknowledged.

The views expressed in this paper do not necessarily reflect those of the European Central Bank.

ISSN 1607-1484 (print)

ISSN 1725-6534 (online) 


\section{CONTENTS}

ABSTRACT

INTRODUCTION

I INTEGRATION OF THE EUROPEAN SECURITIES INDUSTRY: DEFINITION AND DEVELOPMENTS

1.1 Definition of integration of the securities infrastructure

1.2 Factors driving the industry towards integration

1.3 Conflicts of interest

1.4 Recent trends in the securities trading, clearing and settlement industry

1.5 Europeanisation of the use and management of collateral

2 THE ECB'S SPECIFIC INTEREST IN THE INTEGRATION OF THE EUROPEAN SECURITIES INFRASTRUCTURE

2.1 Monetary policy and the functioning of payment systems

2.2 Financial stability

2.3 Efficiency

3 INDUSTRY STRUCTURE, PERFORMANCE AND STABILITY

3.1 Review of theoretical and policy-oriented studies

3.2 Cost studies of securities clearing and settlement: survey and stylised facts

3.3 Technical efficiency versus financial stability

\section{SHAPING THE INFRASTRUCTURE FOR} THE EURO

4.1 Market failures and barriers to integration

4.2 Public and private sector initiatives 33

4.3 The ECB's role and initiatives 34

4.4 Future challenges and options for policy and market design

\section{CONCLUSION}

REFERENCES 


\section{ABSTRACT}

This paper investigates the state and process of integration of the European securities market infrastructure. The integration of financial infrastructures is one of the basic policy goals and key responsibilities of the Eurosystem. The paper finds that, despite the single currency, the euro area securities infrastructure remains highly fragmented and insufficiently integrated. There are still a high number of providers for trading, clearing and settlement, and they are not efficiently connected to one another. The paper also finds that the degree of consolidation varies among different integrated groups of market infrastructure. Economies of scale and scope and positive network externalities inherent in the securities services industry mean that substantial cost savings and increased efficiency can be expected from further integration. The most relevant factors underlying the less advanced areas of integration are likely to be not only persistent cross-border differences in tax regimes, procedures and laws, but also vested interests among users, owners and managers. Current work at the Eurosystem level can be expected to be helpful in promoting further integration. 


\section{INTRODUCTION}

The European securities infrastructure has developed rapidly throughout the last decade. The introduction of the euro has accelerated the development of securities market infrastructures into increasingly integrated and consolidated market structures comprising financial exchanges and clearing and settlement systems. ${ }^{1}$ In Europe, a number of legal and regulatory initiatives and measures have been adopted with the aim of achieving an integrated financial services market. At the global level, there has been growing interest among institutional and individual investors in maximising the positive effects of international portfolio diversification, resulting in a rapid expansion in cross-border securities transactions. In particular, technological innovations have spurred these fundamental changes, causing less dependency on physical market locations and thereby exposing market participants to an increasingly competitive environment in both the domestic and the global arena. The integration process of all types of financial market has also increased the popularity of changes in ownership structure among the institutions which operate these markets. In responding to the new environment, many trading and post-trading service providers have started to behave like regular firms. As a result, exchanges and clearing and settlement organisations have switched from a business model based on a mutual association with inside ownership to a for-profit, sometimes publicly listed company which is accountable to external shareholders.

The integration of European financial and securities infrastructures is an important issue in order to fully exploit the benefits arising from a more homogeneous euro area securities market. Economic theory and empirical evidence suggest that the integration and consolidation of financial markets and infrastructures within the EU would lead to additional business and investment opportunities, lower cost for cross-border transactions, improved opportunities for diversification, and more efficient allocation of capital. Although there is a widespread belief that deepening financial integration is likely to generate benefits on the whole, consolidation may also involve risks. Excessive consolidation could be critical from a competition point of view, as some infrastructure providers may take advantage and abuse their market power. It may also concentrate risks of contagion and systemic failures on a few systems. Therefore, it is essential to monitor the risks associated with the various benefits of diversification and integration carefully and in a timely manner.

The integration and efficiency of the European financial markets is one of the Eurosystem's basic policy goals. This touches on the key responsibilities of the Eurosystem, since efficient and safe securities clearing and settlement systems are a necessary condition for integrated capital markets, the sound execution of monetary policy, the smooth functioning of payment systems and the preservation of financial stability. Guided by these objectives, the ECB has explicitly articulated its interest in carefully monitoring, understanding and promoting the necessary integration of financial market infrastructures. Over several years the ECB has contributed actively on issues relating to the financial integration and consolidation of the European securities infrastructure (ECB, 2000, 2001 and 2003). ${ }^{2}$

Against this background, the present paper analyses current developments and reviews the theory and stylised facts inherent in the current

1 The terms "integration" and "consolidation" are often used as synonyms but do not always refer to the same thing. While "integration" in terms of infrastructure is further defined below, "consolidation" describes the process which leads to a higher degree of concentration, i.e. a smaller number of service providers, as a result of mergers.

2 The third ECB-CFS Central Banking Research Network Conference was devoted to capital markets and financial integration in Europe. One of the main priority areas analysed in the course of the workshop was European securities settlement systems, and a plenary panel discussion was also held on this topic. Further information can be found at http:// www.eu-financial-system.org/ecbcfs.html. 
EU securities infrastructure. The main objective of the paper is to evaluate and assess the current level of integration of the securities infrastructure in the euro area. Moreover, it discusses possible implications for future policy and market design .regarding the integration of the securities infrastructure in Europe. The focus of this study is exclusively on the euro area and its member countries. Given the lack of quantitative and price-based measures, this paper adopts a rather qualitative approach to evaluating the degree and evolution of integration in the securities market infrastructure within Europe.

The remainder of this paper is structured as follows: Section 1 presents a brief description of a common definition of integration that has been applied to the securities infrastructure and explores the main drivers of financial infrastructure integration, before discussing possible conflicts of interest in the consolidation process. It continues by providing a comprehensive overview of the securities infrastructure landscape in Europe, with a particular view to assessing the degree of integration that has been achieved so far. Section 2 sets out the interest of the ECB in market infrastructures. Against this background, Section 3 examines various theoretical concepts, addressing the structure and performance of the securities industry and aspects of its integration. It continues by identifying and examining stylised facts regarding the cost of clearing and settlement, before addressing the effects of integration on financial stability. Section 4 focuses on the concerns of public authorities and analyses their possible roles in shaping a securities infrastructure for the euro area. In particular, it discusses further challenges and possible options for policy and market design. The final section contains the conclusions drawn by the authors of this paper.

\section{INTEGRATION OF THE EUROPEAN SECURITIES INDUSTRY: DEFINITION AND DEVELOPMENTS}

In this section, we provide an overview of recent developments in and the current state of the securities landscape in Europe, with a particular view to identifying recent trends and assessing the degree to which integration of the securities infrastructure has been achieved so far. For this purpose we will first define financial integration in terms of infrastructure.

\section{I.I DEFINITION OF INTEGRATION OF THE SECURITIES INFRASTRUCTURE}

A careful analysis of the extent to which the European securities infrastructure is integrated requires a common understanding of integration in terms of infrastructure. Various definitions and approaches to measure financial integration at the micro and the macro levels have been put forward in literature. ${ }^{3}$ In accordance with Baele et al. (2004), we adopt the following broad definition of financial integration: ${ }^{4}$

The market for a given set of financial instruments and/or services is fully integrated if all potential market participants with the same relevant characteristics:

1. face the same set of rules when they decide to deal with those financial instruments and/ or services;

2. have equal access to the above-mentioned set of financial instruments and/or services; and

3. are treated equally when they are active in the market.

3 See, among others, Ayoso and Blanco (1999) and Stockmann (1988). For a more detailed discussion of methodologies, indicators, and results of more recent studies documenting the progress in EU financial integration, see Adam et al. (2003), Adjaouté and Danthine (2003), Baele et al. (2004), Cabral et al. (2002), ECB (2003), Gaspar et al. (2002), Hartmann et al. (2003), and London Economics (2002).

4 See Baele et al. (2004) for a detailed discussion of this definition. 
The proposed definition of financial integration is thus based on three important conditions: (i) same set of rules, (ii) market participants' equal access to the market, and (iii) market participants' equal treatment in the market.

In the field of securities infrastructures, the condition of the "same set of rules" will be met if, on a European-wide scale, providers of trading, clearing and settlement services operate on the basis of the same technical procedures, the same prices, the same legal framework, the same business practices, etc.

According to the condition of "equal access", integration implies access for all users to the same services and financial instruments on the same conditions, regardless of the location of the user or provider. Thus, perfect integration in the securities infrastructure requires the same and open access to trading, clearing and settlement platforms for their users or providers.

In addition, once equal access has been granted, perfect integration implies that market participants are treated equally and are not discriminated against irrespective of their location or origin. In the context of securities systems it might be useful to distinguish between equal treatment of participants within and across systems. This is because of the multiplicity of securities trading, clearing and settlement systems required to access (directly or indirectly) many national systems that provide very different types of services, have different technical requirements/market practices (settlement periods, rules relating to corporate actions and issuance practice, etc.), and operate within different tax and legal frameworks.

Consequently, our evaluation of the integration of the European securities market infrastructure will be based on the above-stated definition of financial integration. In this context, some further clarification is needed in terms of the terminology used. Indeed, the terms "integration" and "consolidation" are often used as synonyms, but do not always refer to the same thing. Integration as defined above enables the service users to pay the same price for the same product or service, regardless of their location. In particular, the costs of trading, clearing and settlement should not distort investment decisions. Thus, it should not make a difference whether a final investor in Finland, for instance, buys or sells a security issued in Finland or France in terms of clearing and settlement costs. Along the same lines, it should not make a difference to a Finnish commercial bank whether it uses Finnish or French securities as collateral to obtain central bank credit.

Consolidation describes the process of concentration in the trading, clearing and settlement industry. It concerns not only structural aspects such as mergers and acquisitions, but also outsourcing, alliances, joint ventures and reorganisations within financial institutions. As such, consolidation not only facilitates integration, but may also help to reduce the cost of trading, clearing and settlement, by making use of scale economies and network externalities. Therefore, consolidation is a key concept for integration and rationalisation in the euro area. If there were one single provider for trading, clearing and settlement in the euro area, differences attributable to location would necessarily disappear. In other words, consolidation is one (very effective) way of achieving integration, but not the only one. In particular, it cannot be argued that the existence of more than one provider for trading, clearing and settlement services is a clear sign of a lack of integration. The actual degree of integration typically lies somewhere between the two extremes of full segmentation and perfect integration.

\section{I.2 FACTORS DRIVING THE INDUSTRY TOWARDS INTEGRATION}

The securities infrastructure industry is in the midst of profound change. Nowadays stock exchanges, custodians and clearing and
INTEGRATION OF

THE EUROPEAN SECURITIES

INDUSTRY:

DEFINITION AND DEVELOPMENTS 
settlement providers increasingly operate on a global scale in a dynamic, fast-paced and increasingly competitive environment.

The continued globalisation of financial and securities markets reflects growing demand on the part of institutional and individual investors who wish to derive maximum benefit from international risk and portfolio diversification, resulting in a rapid expansion of cross-border trading, custody, clearing and settlement activity. Developments in information and communication technology have increased pressure for further consolidation of securities trading, clearing, custody and settlement on a global scale. The introduction of the euro reinforced increased cross-border securities business, coupled with growing pressure by institutional investors to reduce the cost and complexity of international trading. Moreover, legal harmonisation and regulatory initiatives have been introduced at the European level with the aim of achieving an integrated securities market infrastructure.

In this context, economies of scale and scope and network externalities are further accelerating the need for more integrated and efficient infrastructure, comprising stock exchanges, trading platforms, and electronic networks, and clearing and settlement facilities at both the global and the domestic level.

Economies of scale are usually a result of the need for service providers to create a "critical mass" of customers in order to reap the benefit of sizeable investments in information technology and in the establishment of efficient communication networks. To the extent that securities infrastructure providers are successful in attracting a significant number of issuers and participants and in achieving higher liquidity, these set-up costs may be spread over a wider number of transactions. Accordingly, services might then be provided at lower cost. Increased integration of different systems is likely to enable service providers to benefit from further economies of scale, thereby reducing expenditure related to trade, clearing settlement and custody services.

The concept of scope economies stems from requests from customers for a wide range of products and services at a relatively low cost. It refers to savings from the same investment supporting multiple profitable activities and services. In theory, two or more integrated stock exchanges or SSSs would together be able to develop new products and services at a lower unit cost than separately. The integration process would allow a wide range of services to be provided without any need for customers to use different interfaces and comply with a variety of standards in order to reach different markets. Using a single point of entry to one system, a participant can, at a relatively low cost, have access to different segments of the securities markets, at both the national and the international level.

The concept of network externalities represents an important field in economics, as it applies to a variety of industries, such as telecommunications, airlines, railroads, etc. (Shy, 2001). In a typical network, the addition of a new consumer or network participant increases the value of the network for all participants. This effect is called a network effect or network externality. In the context of securities markets, trading, clearing and settlement systems bear the characteristics of a network industry, as the benefit to one market participant transacting, clearing or settling in a given platform or system increases when another participant also chooses to do business in that network. ${ }^{5}$ Integration of financial infrastructures is likely to reinforce and stimulate network externalities.

\section{I.3 CONFLICTS OF INTEREST}

Changing roles within the securities industry have complicated the interaction of the various vested interests. These vested interests in the

\footnotetext{
5 Liquidity plays a pivotal role in financial exchange markets where order-flow attracts order-flow. For example, according to Economides (1993) and Economides and Siow (1988), the spatial consolidation of markets tends to increase liquidity.
} 
securities industry can be viewed from the perspective of (i) users, (ii) owners, and (iii) management of the systems. Following this line of reasoning, Koeppl and Monnet (2003) highlight the fact that conflicts of interest might be detrimental to further integration. ${ }^{6}$

\section{THE USERS' PERSPECTIVE}

Generally speaking, the primary interest of users is to obtain the best price for a given level of service, although users of clearing and settlement services are also concerned about safety. In their search for low-cost and safe services, users of clearing and settlement services prefer to be part of a larger system (in terms of number of participants and securities processed) so as to maximise the number of potential counterparties within the same system. In other ways, however, the users of clearing and settlement systems are a heterogeneous group. They may or may not also be owners of clearing and settlement systems and this is reflected in differences in their specific interests. Those who are users only have a preference for a highly efficient, integrated infrastructure for the entire chain of securities transactions, i.e. trading, matching, clearing, settlement and custody. The benefits of an integrated structure are relatively low transaction costs, the high speed of settlement and the low rate of settlement default. It is in the interest of users to have an "open architecture", providing them with the option of selecting particular types of service rather than being bound to use the entire segment of the transaction chain, including trading, clearing, settlement and custody. Users would prefer to internalise the segments that are considered profitable, while other segments could be supplied by a clearing and settlement system. ${ }^{7}$ A fragmented infrastructure also allows user-owners to attract participants by offering them integrated solutions based on an internal processing infrastructure. However, if market players were to set up their own trading platforms, they could benefit from using the existing clearing and settlement infrastructure to allow their users to route transactions from their platform through the same systems that they use for other transactions.

In particular, small and medium-sized players that operate on a local basis tend to be more satisfied with the current clearing mechanism (i.e. settlement netting) that is offered by the domestic settlement systems. ${ }^{8}$ Accordingly, these users are unwilling to bear any costs of integration if they intend to continue operating at the local level. However, once the barriers to efficient clearing and settlement have been removed, the location of the users is less relevant. Local players would therefore have an incentive to increase their cross-border business and would support consolidation in the clearing and settlement infrastructure to the extent that it reduces the cost for them of accessing foreign markets.

\section{THE OWNERS' PERSPECTIVE}

Some owners will oppose consolidation. A less efficient and fragmented system offers an arbitrage opportunity of attracting new customers - mainly small and medium-sized users - as members. Therefore, any consolidation within the clearing and settlement structure would negatively affect the business of these owners. Moreover, the owners (generally banks) may have a vested interest in preventing the "owned" entities from providing banking services (e.g. offering credit facilities). Owners can face conflicts of interest to the extent that they are normally users and competitors at the same time. On the other hand, one advantage of having users as owners is that they can ensure that the clearing and settlement system does not abuse any monopoly powers. In the case of vertical consolidation, the stock exchange (as the single owner of the clearing and settlement infrastructure) could oppose horizontal

6 See also Section 3.1 for further explanation.

7 For example, in the event that clearing and settlement is a profitable business, they would prefer to keep the trading order within their own organisation (an in-house system) rather than sending the trading instructions directly to a clearing and settlement system.

8 See also Giovannini Group (2003).
I INTEGRATION OF

THE EUROPEAN SECURITIES

INDUSTRY:

DEFINITION AND

DEVELOPMENTS 
consolidation that would reduce its control over the other components of the value chain. Moreover, keeping the infrastructure "closed" may be the only way of maximising the economies of scope, thereby reducing costs and increasing profits.

\section{THE MANAGEMENT'S PERSPECTIVE}

The interests of management in the clearing and settlement industry are characterised by the existence of the principal-agent relationship. Management may resist solutions that would remove them from their position and, for this reason, tends to prefer a fragmented clearing and settlement environment. Fragmentation may preserve local infrastructures which might not be efficient enough to survive in an integrated European market.

\section{I.4 RECENT TRENDS IN THE SECURITIES TRADING, CLEARING AND SETTLEMENT INDUSTRY}

The establishment of European Economic and Monetary Union (EMU) has accelerated a process of integration in the securities trading, clearing and settlement industry within the euro area and beyond; investors no longer face currency risks with regard to their euro area holdings and are increasingly diversifying their portfolios. Developments in technology and legal harmonisation at the European level have also been promoting further consolidation. As a consequence of these developments, there has been a rapid expansion in the number and volume of securities that are traded, cleared and settled across borders in the euro area. However, the costs of cross-border transactions have remained high when compared with domestic trading, clearing and settlement costs. ${ }^{9}$ One reason for this is that cross-border trading and post-trading activities often involve cross-system trading, clearing and settlement, as counterparties located in different countries often do not use the same trading, clearing and settlement systems.
International consolidation of the securities market infrastructure (especially of stock exchanges, central securities depositories and central counterparties) can help to address the increased need for cross-system trading, clearing and settlement. During the last few years the industry has taken up these calls in several ways. As a consequence, some degree of consolidation as a means of integration in the securities market infrastructure has been achieved within the European Union, in the form of both structural changes and strategic measures. Three different types of consolidation in the trading, clearing and settlement industry can be distinguished.

Horizontal consolidation involves legal mergers of institutions or systems providing similar services in different markets or jurisdictions, such as the merger of two or more securities settlement systems.

Vertical consolidation contains legal mergers of institutions providing different but integrated services, such as integration of different activities which are processed along the securities transaction chain within a single entity or group of entities.

Lateral consolidation includes the promotion, diffusion and sharing of securities trading, clearing and settlement services, technologies, special mechanisms and schemes, such as delivery versus payment (DVP) facilities, expansion of central counterparty functions, central bank money settlement facilities, and implementation of securities lending and borrowing programmes.

The following sections provide an overview of recent trends of consolidation in the trading, clearing and settlement industry and identify areas where integration has not been achieved.

9 See Section 3 for further details regarding studies and comparisons of trading, clearing and settlement costs. 


\section{I.4.I STOCK EXCHANGES}

In recent years, the securities exchange industry has experienced a period of rapid transformation and restructuring. Whereas numerous new cooperative agreements, joint ventures and merger plans between exchanges have been announced, the number of deals which have been completely implemented as opposed to those which have been dropped or which have failed has been strikingly low. A comprehensive survey of historical alliances, mergers and other forms and attempts of cooperation between stock and derivatives exchanges illustrating various aspects and models of consolidation has been presented in a number of studies (Cybo-Ottone et al., 2002; Domowitz, 1995; Domowitz and Steil, 1999; Hasan and Schmiedel, 2004; Lee, 1998).

Table 1 provides an updated overview of the securities exchange industry, highlighting most of the merger initiatives undertaken by various stock and derivatives exchanges in the euro area in the period from 1999 to 2004.

Historically, the securities exchange industry has been fragmented along national lines, thereby leaving substantial room for

\section{Table I Stock and derivatives exchanges in the euro area, |999-2004}

\begin{tabular}{|c|c|c|}
\hline Country & January 1999 & October 2004 \\
\hline Austria & Vienna Stock Exchange & Vienna Stock Exchange \\
\hline Belgium & $\begin{array}{l}\text { Belgium Stock Exchange } \\
\text { BELFOX (derivatives) }\end{array}$ & Euronext Brussels \\
\hline Finland & HEX Integrated Markets & OMX Exchanges \\
\hline France & $\begin{array}{l}\text { Paris Stock Exchange MONEP } \\
\text { MATIF } \\
\text { Nouveau Marché }\end{array}$ & Euronext Paris \\
\hline Germany & $\begin{array}{l}\text { Deutsche Börse AG } \\
\text { Berliner Börse } \\
\text { Bremen Stock Exchange } \\
\text { Börse Düsseldorf } \\
\text { Hamburg Hanseatic Stock Exchange } \\
\text { Lower Saxony Stock Market at Hanover } \\
\text { Bayrische Börse AG } \\
\text { Börse Stuttgart AG }\end{array}$ & $\begin{array}{l}\text { Deutsche Börse AG } \\
\text { Berliner Börse (merged with Bremen Stock } \\
\text { Exchange) } \\
\text { Börse Düsseldorf } \\
\text { BÖAG Börsen AG (The Hamburg } \\
\text { Hanseatic Stock Exchange and The Lower } \\
\text { Saxony Stock Market at Hanover) } \\
\text { Bayrische Börse AG Börse Stuttgart AG }\end{array}$ \\
\hline Greece & $\begin{array}{l}\text { Athens Stock Exchange S.A. } \\
\text { Athens Derivative Exchange S.A. } \\
\text { Thessaloniki Stock Exchange Center }\end{array}$ & Athens Exchange \\
\hline Ireland & Irish Stock Exchange & Irish Stock Exchange \\
\hline Italy & Borsa Italiana S.p.A. & Borsa Italiana S.p.A. \\
\hline Luxembourg & Luxembourg Stock Exchange & Luxembourg Stock Exchange \\
\hline Netherlands & Amsterdam Stock Exchange & Euronext Amsterdam \\
\hline Portugal & $\begin{array}{l}\text { Lisbon Stock Exchange Oporto } \\
\text { Derivative Exchange }\end{array}$ & Euronext Lisbon \\
\hline Spain & $\begin{array}{l}\text { Barcelona Stock Exchange } \\
\text { Bilbao Stock Exchange } \\
\text { Stock Exchange of Madrid } \\
\text { Valencia Stock Exchange } \\
\text { MEFF Renta Fija } \\
\text { MEFF Renta Variable }\end{array}$ & $\begin{array}{l}\text { Barcelona Stock Exchange (BME) } \\
\text { Bilbao Stock Exchange (BME) } \\
\text { Stock Exchange of Madrid (BME) } \\
\text { Valencia Stock Exchange (BME) } \\
\text { MEFF Renta Variable (BME) } \\
\text { MEFF Renta Variable (BME) }\end{array}$ \\
\hline
\end{tabular}


operational and technical inefficiencies (Hasan et al., 2003; and Schmiedel, 2003). As shown in Table 1, 31 different securities exchanges coexisted in 1999 in the countries that now comprise the euro area. With regard to financial integration, Table 1 reveals that there have been some consolidation efforts towards more integrated infrastructures, as the total number of securities exchanges in those countries had decreased to 22 by October 2004 .

At the national level, many of the recent consolidation deals have been mergers of regional exchanges (e.g. in Germany) and between the cash and derivatives markets. In August 2002 the Athens Stock Exchange and the Athens Derivatives Exchange merged to form the Athens Exchange. The transformation of the cash and derivatives exchanges also smoothed the way for further cross-border consolidation. In February 2002 the Portuguese exchange Bolsa de Valores de Lisboa e Porto (formed through the restructuring of the former Lisbon Stock Exchange Association and the Porto Derivatives Exchange Association) joined the Euronext Group to become Euronext Lisbon as a wholly owned subsidiary of the Euronext Group. Another national consolidation initiative has been the creation of a new holding company comprising all the Spanish markets under the name Bolsas y Mercados Españoles.

A few complete horizontal cross-border mergers have been achieved. The most prominent example of a pan-European exchange was the merger of the Paris, Brussels and Amsterdam exchanges under the name Euronext in 2000.

Alongside the earlier initiative of Deutsche Börse to integrate within one company the functions of an exchange, a clearing house and a central depository, another strategy of vertical integration has been pursued both inside and outside the euro area. In 2003 the OM Group and HEX, the operator of the Finnish Exchange, merged to form OMHEX, thereby becoming northern Europe's largest securities market and a leading provider of market place services and solutions for the financial and energy markets. HEX Integrated Markets not only includes Stockholmsbörsen, Helsinki Stock Exchange, Vilnius Stock Exchange and Tallinn Stock Exchange at the horizontal level, it also owns the Central Securities Depositories in Finland, Estonia and Latvia. In 2004 OMHEX was renamed OMX, and its activities are now marketed under that name.

While consolidation has proceeded at a remarkable pace in the period under consideration, the securities exchange market in the euro area still remains fragmented and the ultimate outcome of the consolidation process is uncertain. There have been more domestic than cross-border mergers. As a result of the consolidation process, the securities exchange industry has evolved towards a structure of more integrated exchange groups. However, these blocs or groups of exchanges vary in the degree and intensity of their integration.

\section{I.4.2 ICSDS AND CSDS}

In a similar manner to the evolution of the securities exchange sector, there has been consolidation in the post-trading infrastructure in recent years. Several mergers or other forms of institutional cooperation between securities infrastructure providers have taken place. In the post-trading sector, this consolidation process has happened at both the vertical and the horizontal level. Although integration of the post-trading industry has mostly occurred at the local national level, a few significant mergers and alliances have taken place internationally. At present, however, the panEuropean clearing and securities settlement infrastructure still remains fragmented. Table 2 compares the total number of central securities depositories $(\mathrm{CSDs})^{10}$ located in the countries

10 In this paper, a CSD is an institution that holds securities, thus enabling securities transactions to be processed by means of book entries. Physical securities may be immobilised by the depository or securities may be dematerialised (so that they exist only as electronic records. Unless otherwise noted, references in this paper include the international central securities depositories (ICSDs) Euroclear and Clearstream. 


\section{Table 2 CSDs in the euro area, 1999-2004}

\begin{tabular}{lll}
\hline Country & January 1999 & October 2004 \\
Austria & OeKB & OeKB \\
Belgium & NBB-SSS & NBB-SSS \\
& CIK & Euroclear Bank \\
Finland & Euroclear & \\
France & APK & APK \\
Germany & Sicovam & Euroclear France (former Sicovam \\
Greece & Deutsche Börse Clearing (DBC) & Clearstream Frankfurt (former DBC) \\
& BOGS & BOGS \\
Ireland & CSD SA & CSD SA \\
& CBISSO & NTMA \\
Italy & NTMA & \\
& Monte Titoli & Monte Titoli \\
Luxembourg & CAT & \\
Netherlands & Cedel & Clearstream Luxembourg (former Cedel) \\
Portugal & Necigef & Euroclear Netherlands (former Necigef) \\
& Interbolsa & Interbolsa \\
Spain & SITEME & SITEME \\
& CADE & Iberclear \\
& SCLV & SCL Bilbao \\
& Espaclear & SCL Barcelona \\
& SCL Barcelona & \\
& SCL Valencia & SCL Valencia \\
& & \\
\hline & & \\
& &
\end{tabular}

Source: ECB (2004).

Note: Greece joined the euro area on 1 January 2001.

that now comprise the euro area at the beginning of 1999 with the total in October 2004.

In 1999 there were 23 domestic CSDs in what are now the 12 countries of the euro area. This was a result of differing historical, institutional, technical and legal environments, as well as of the existence of different currencies. In most of those countries one single CSD supported the activity of the entire securities industry, while in some countries the role of each CSD was limited to a certain segment of the market (e.g. settlement of public debt, equities, corporate debt). They served the needs of the local market which they were designed to support. The national features of most domestic CSDs led to a fragmentation of the industry, which was thus unable to adequately serve the needs of participants

operating across EU markets. Cross-border transfers of securities in the EU have therefore relied extensively on the use of alternative channels, namely custodian banks or ICSDs. ${ }^{11}$

Although the total number of CSDs in those countries only decreased from 23 in 1999 to 18 in 2004, several corporate CSD groups were formed over this period. It is also interesting to note that no two CSDs belonged to the same group in 1999. However, several groups of CSDs have since undertaken consolidation initiatives.

At the local level, reforms towards horizontal consolidation were carried out in Spain, where a new single CSD for all instruments (Iberclear) was formed from the merger of the

11 See also ECB (2000). 
two central depositories, SCLV (for equities and corporate bonds) and CADE (the bookentry system for public debt). In Italy, the national central depository (Monte Titoli) took over settlement functions, which had been managed by the Banca d'Italia until 2003. Similar developments also took place outside the euro area. For example, in the United Kingdom the central depository (CREST) internalised settlement functions for government securities from other systems.

At the euro area level, horizontal consolidation can be exemplified by the merger prior to the introduction of the euro of Deutsche Börse Clearing and Cedelbank Luxembourg under the name Clearstream International, and the establishment of the Euroclear Group. Clearstream International comprises Clearstream Frankfurt and the international CSD Clearstream Luxembourg. The Euroclear Group was formed in 2001 from the merger of Euroclear and the French national CSD Sicovam, going on to incorporate Necigef (the Netherlands) in 2002, CREST (United Kingdom) in 2002 and CIK (Belgium) in 2005. Euroclear also took over the functions of CBISSO (the settlement system for Irish government bonds) in 2000 .

At the EU level, in 2003 the Swedish OM Group made a successful offer for the whole of the Finnish HEX Group (including the APK) to form OMHEX. ${ }^{12}$ The new group is aiming to rapidly develop an integrated securities infrastructure for the Nordic and Baltic countries, and is thereby hoping to bring efficiency gains to the post-trading landscape in the region by way of horizontal integration. ${ }^{13}$ Together with the CSDs of Latvia and Estonia, the APK currently belongs to the OMHEX Group. In April 2004 OMHEX announced its intention to sell the APK to the VPC. As a result of this deal, the new CSD group would operate organisationally as one company but the actual business would be conducted by separate legal entities, one in Sweden and one in Finland. The long-term plan is for both CSDs to use a common technological platform.
Vertical consolidation initiatives have been seen at the local level in Germany, Italy and Spain. In Germany and Italy, the stock exchanges have become the main or exclusive shareholder of the respective clearing and settlement systems. In Spain, the stock exchange and the post-trading systems are now organised under the single holding company Bolsas y Mercados Españoles (BME).

A final observation can be made according to the operation of central securities depository activities. Traditionally, Eurosystem national central banks (NCBs) have played an operational role in the settlement of securities. Today, most of the settlement related tasks have been transferred to private entities. Only a few NCBs still act as a CSD or registrar for certain government or other securities.

\subsubsection{CENTRAL COUNTERPARTIES}

Since the introduction of the euro, the business of central counterparty clearing has developed rapidly in Europe as a means of lowering the risks relating to securities transactions. Until recently, initiatives to enhance the efficiency and stability of systems focused primarily on the derivative markets, but they have now increasingly been extended to the equity and bond market as well. In the area of central counterparty $(\mathrm{CCP})^{14}$ clearing, the process of consolidation has been relatively more pronounced than in the field of trading and settlement. Several central counterparty clearing houses already exist in the euro area and a number of mergers and alliances are currently under consideration or being implemented. Table 3 shows the total number of CCPs located in the euro area at the beginning of 1999 and at the end of 2004.

12 OMHEX was renamed OMX in August 2004. It is the name under which all activities are now marketed.

13 The venture covers only the Finnish and Swedish CSDs, not the Baltic CSDs (they remain part of the OMX)

14 In this paper, a CCP is regarded as an institution that places itself between the counterparties when contracts are traded in financial markets, becoming the buyer to every seller and the seller to every buyer. 


\section{Table 3 CCPs in the euro area, 1999-2004}

\begin{tabular}{|c|c|c|}
\hline Country & January 1999 & October 2004 \\
\hline Austria & Vienna Stock Exchange (derivatives) & Vienna Stock Exchange (derivatives) \\
\hline Belgium & BELFOX (derivatives) & None \\
\hline Finland & HEX (derivatives) & OMX (derivatives) \\
\hline France & $\begin{array}{l}\text { Bourse de Paris (SBF) (equities and options); } \\
\text { Matif (derivatives; subsidy of SBF) } \\
\text { Clearnet (repos, gov. bonds; subsidy of Matif) }\end{array}$ & $\begin{array}{l}\text { LCH.Clearnet SA (deriv., repos, securities, also } \\
\text { for markets in BE, NL, PT and for MTS markets) }\end{array}$ \\
\hline Germany & Eurex Clearing (derivatives) & Eurex Clearing (derivatives, repos, securities) \\
\hline Greece & ADECH (derivatives) & ADECH (derivatives) \\
\hline Ireland & None & None \\
\hline Italy & $\mathrm{CC} \& \mathrm{G}$ (derivatives) & CC\&G (derivatives, securities, also for MTS Italy) \\
\hline Luxembourg & None & None \\
\hline Netherlands & $\begin{array}{l}\text { Effectenclearing (securities); } \\
\text { EOCC (derivatives) }\end{array}$ & None \\
\hline Portugal & BVLP (derivatives) & None \\
\hline Spain & $\begin{array}{l}\text { MEFF Renta Fija (deriv. on debt instr.) } \\
\text { MEFF Renta Variable (deriv. on equities) }\end{array}$ & $\begin{array}{l}\text { MEFF Renta Fija (repos, gov. bonds, deriv. on } \\
\text { debt instr.) } \\
\text { MEFF Renta Variable (derivatives on equities) }\end{array}$ \\
\hline
\end{tabular}

From Table 3, it can be seen that there was between January 1999 and October 2004 a relatively sharp decline in the number of CCPs for financial instruments (derivatives, securities, repos) in the countries that now comprise the euro area. Most of the horizontal defragmentation arrangements were driven by developments in the Euronext countries, i.e. Belgium, France, the Netherlands and Portugal. At the local level, three French CCPs merged into Clearnet SA in 1999. At the EU level, Clearnet took over the activities of the CCPs in Belgium and the Netherlands in 2001. The most systemically important consolidation initiative has been the December 2003 merger of London Clearing House Ltd and Clearnet SA to create LCH.Clearnet. In 2004 LCH.Clearnet $\mathrm{SA}$ took over the activities of the Portuguese CCP.

\section{I.4.4 CUSTODIANS}

Custodian banks are intermediaries which provide foreign investors with custody and settlement services in their domestic CSDs.
Unlike CSDs, they do not act as primary depositories. The ability of local custodians to facilitate communication between foreign banks and domestic CSDs and to provide local expertise has greatly contributed to the development of the cross-border trading of securities over the past 30 years. Global custodians, i.e. custodians which have extended their range of services in order to cover several markets, use a network of subcustodians (local agents, including their local branches) to provide institutional investors with a single gateway for settling their crossborder portfolio in many countries. Although global custodians also provide internal settlement of securities in their own books, they specialise more in the custody function, thereby holding a range of assets on behalf of their customers. These include equities, government bonds, corporate bonds, other debt instruments, mutual fund investments, warrants and derivatives.

INTEGRATION OF THE EUROPEAN SECURITIES

INDUSTRY: 


\section{Table 4 Assets held with the ten largest global custodians, 2004}

\begin{tabular}{|c|c|c|c|c|}
\hline Company & $\begin{array}{l}\text { Worldwide } \\
\text { assets } \\
\text { (USD billions) }\end{array}$ & $\begin{array}{l}\text { Cross-border } \\
\text { assets } \\
\text { (USD billions) }\end{array}$ & $\begin{array}{c}\text { Share of } \\
\text { cross-border } \\
\text { assets in worldwide } \\
\text { assets (percentage) }\end{array}$ & Reference date \\
\hline State Street & 9,100 & - & - & 30 June 2004 \\
\hline The Bank of New York & 8,906 & 2,494 & 28.0 & 30 Sep. 2004 \\
\hline JPMorgan & 8,014 & 1,897 & 23.7 & 31 Mar. 2004 \\
\hline Citigroup & 6,640 & 4,405 & 66.3 & 31 Mar. 2004 \\
\hline BNP Paribas Securities Services & 2,958 & 2,363 & 79.9 & 30 Sep. 2004 \\
\hline Mellon Group & 2,946 & 800 & 27.2 & 30 Sep. 2004 \\
\hline UBS AG & 2,436 & - & - & 30 Sep. 2004 \\
\hline Northern Trust & 2,400 & 866 & 36.1 & 30 Sep. 2004 \\
\hline HSBC Securities Services & 1,572 & 755 & 48.0 & 31 May 2004 \\
\hline Société Générale & 1,329 & 784 & 59.0 & 31 Mar. 2004 \\
\hline Others & 13,065 & - & - & \\
\hline Total (41 largest global custodians) & 59,366 & - & - & \\
\hline
\end{tabular}

Source: ECB calculations. (C) globalcustody.net (2004) and reproduced from the full tables at www.globalcustody.net

Note: Worldwide assets are composed of cross-border assets (i.e. where the investor and the issuer are located in different countries), and domestic assets (i.e. where the investor and the issuer are located in the same country). Some companies do not publish a breakdown of their total worldwide figures. Data are available only for the 41 largest global custodians.

Today major custodians access and serve up to 100 markets and provide an increasingly sophisticated range of services. The significance of the custody business can be measured by the total value of assets held under custody. In 2004 the total value of worldwide assets held with the largest global custodians was more than USD 59,000 billion, as shown in Table 4. For example, State Street provided

\section{Chart I Custodian banks - worldwide assets under custody, 2004}

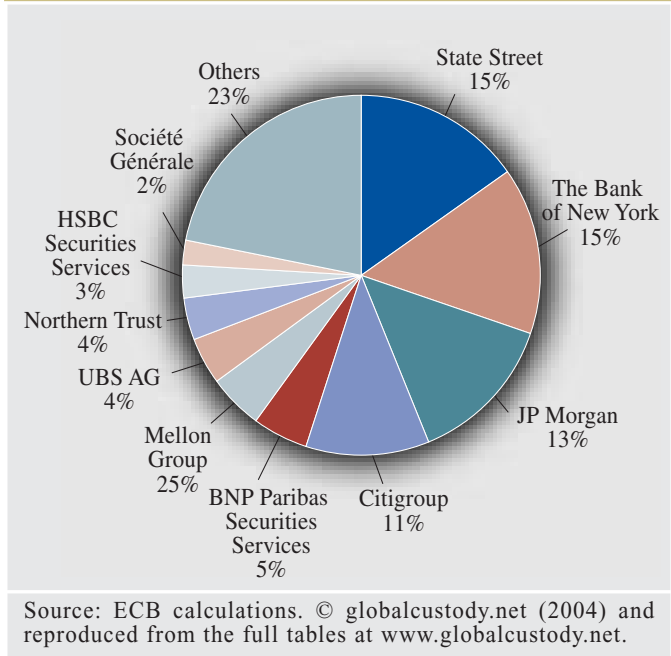

custody services for assets valued at USD 9,100 billion (see Table 4). All of the top ten firms held assets worldwide exceeding USD 1,000 billion. The relatively high proportion of cross-border assets in the total value of assets of some providers highlights the fact that market participants (e.g. institutional investors, money managers and broker/dealers) make substantial use of custody services across

\section{Chart 2 Custodian banks - Geographical distribution of worldwide assets under} custody, 2004

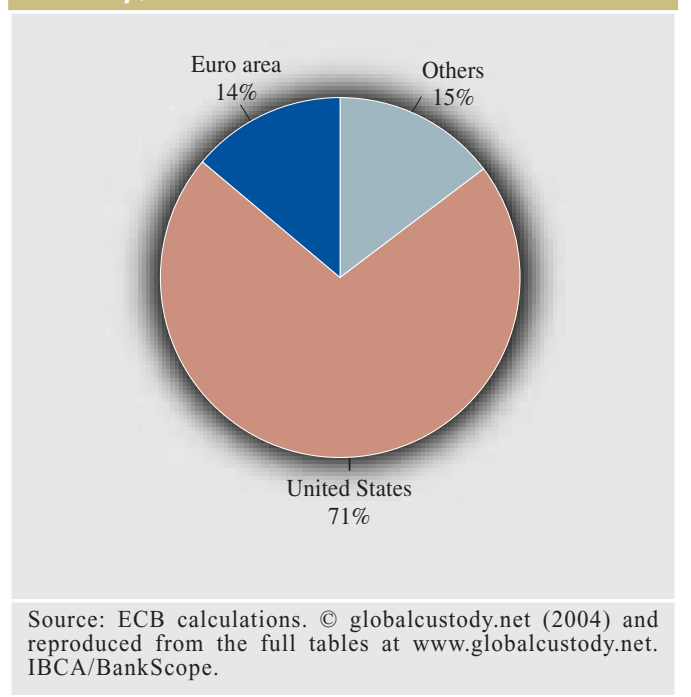




\section{Table 5 Total assets under custody, 2000-04}

\begin{tabular}{|c|c|c|c|c|c|c|}
\hline \multicolumn{7}{|l|}{ (USD billions) } \\
\hline Assets under custody & & 2000 & 2001 & 2002 & 2003 & 2004 \\
\hline \multicolumn{7}{|l|}{ Worldwide } \\
\hline & All & 37,340 & 38,908 & 45,144 & 54,718 & 59,430 \\
\hline & 5 largest & 26,400 & 26,861 & 28,174 & 34,679 & 35,618 \\
\hline & 10 largest & 33,684 & 34,604 & 36,737 & 44,049 & 46,324 \\
\hline & 20 largest & 37,153 & 38,519 & 43,422 & 51,862 & 54,907 \\
\hline & Max. & 6,700 & 6,800 & 6,700 & 9,400 & 9,100 \\
\hline & Min. & 14 & 14 & 12 & 2 & 7 \\
\hline & Median & 588 & 462 & 495 & 450 & 379 \\
\hline & Average & 1,556 & 1,496 & 1,290 & 1,403 & 1,292 \\
\hline & $\mathrm{N}$ & 24 & 26 & 35 & 39 & 46 \\
\hline \multicolumn{7}{|l|}{ Cross-border } \\
\hline & All & & 13,218 & 12,360 & 17,288 & 18,819 \\
\hline & 5 largest & & 8,820 & 7,982 & 11,977 & 12,510 \\
\hline & 10 largest & & 11,589 & 10,589 & 15,388 & 16,356 \\
\hline & 20 largest & & 13,218 & 12,276 & 17,117 & 18,673 \\
\hline & Max. & & 2,300 & 2,000 & 4,251 & 4,405 \\
\hline & Min. & & 15 & 2 & 2 & 7 \\
\hline & Median & & 392 & 208 & 170 & 298 \\
\hline & Average & & 661 & 475 & 596 & 724 \\
\hline & $\mathrm{N}$ & & 20 & 26 & 29 & 26 \\
\hline \multicolumn{7}{|l|}{ Domestic } \\
\hline & All & & 24,740 & 27,196 & 31,796 & 25,649 \\
\hline & 5 largest & & 18,150 & 18,552 & 22,713 & 18,442 \\
\hline & 10 largest & & 22,994 & 22,991 & 27,629 & 22,534 \\
\hline & 20 largest & & 24,740 & 26,485 & 31,291 & 25,411 \\
\hline & Max. & & 5,000 & 5,000 & 6,959 & 6,412 \\
\hline & Min. & & 113 & 98 & 30 & 1 \\
\hline & Median & & 384 & 460 & 484 & 383 \\
\hline & Average & & 1,302 & 1,088 & 1,223 & 987 \\
\hline & $\mathrm{N}$ & & 19 & 25 & 26 & 26 \\
\hline
\end{tabular}

Source: ECB calculations. (C) globalcustody.net (2000-04) and reproduced from the full tables at www.globalcustody.net.

Note: This table is based on data supplied to globalcustody.net by individual global custodian banks. Some providers counted in the worldwide figures have not supplied a breakdown of their total figures. It should be noted that there is a degree of double-counting, with some assets being reported by banks acting in the capacity of sub-custodian and also by the corresponding global custodian. borders for the handling of their worldwide securities portfolios. In particular, the share of cross-border holdings is relatively higher for European companies (e.g. BNP Paribas (80\%), Citigroup (66\%), Société Générale (59\%)) than for the US providers. Chart 1 plots the relative market share of assets held with the top ten global custodians. Chart 2 provides information on the geographical distribution of worldwide assets under custody for the year 2004. When assets are grouped according to the location of the parent company, it becomes apparent that in 2004 only $14 \%$ of assets were held with custodians located in the euro area, compared with the $71 \%$ held with US custodian banks.
INTEGRATION OF THE EUROPEAN SECURITIES INDUSTRY: DEFINITION AND DEVELOPMENTS

Tables 5 and 6 provide descriptive statistics of the development and market shares of the global custody market in the period from 2000 to 2004. As can been seen from Table 5, there has been substantial overall growth of almost $60 \%$ in the total value of assets under custody during the period under consideration.

When interpreting the statistics, it should be borne in mind that the high growth rate in the custody business is driven by a combination of factors, global trends, and data and reporting sensitivity. First, the growing global custody business might be explained by the increasing demand for cross-border assets for emerging markets and for a wider range of financial 


\begin{tabular}{|c|c|c|c|c|c|}
\hline \multicolumn{6}{|l|}{ (USD billions) } \\
\hline Market share & 2000 & 2001 & 2002 & 2003 & 2004 \\
\hline \multicolumn{6}{|l|}{ Worldwide } \\
\hline 5 largest & 70.7 & 69.0 & 62.4 & 63.4 & 59.9 \\
\hline 10 largest & 90.2 & 88.9 & 81.4 & 80.5 & 77.9 \\
\hline 20 largest & 99.5 & 99.0 & 96.2 & 94.8 & 92.4 \\
\hline Max. & 17.9 & 17.5 & 14.8 & 17.2 & 15.3 \\
\hline Min. & 0.0 & 0.0 & 0.0 & 0.0 & 0.0 \\
\hline Median & 1.6 & 1.2 & 1.1 & 0.8 & 0.6 \\
\hline Average & 4.2 & 3.8 & 2.9 & 2.6 & 2.2 \\
\hline $\mathrm{N}$ & 24 & 26 & 35 & 39 & 46 \\
\hline \multicolumn{6}{|l|}{ Cross-border } \\
\hline 5 largest & & 66.7 & 64.6 & 69.3 & 66.5 \\
\hline 10 largest & & 87.7 & 85.7 & 89.0 & 86.9 \\
\hline 20 largest & & 100.0 & 99.3 & 99.0 & 99.2 \\
\hline Max. & & 17.4 & 16.2 & 24.6 & 23.4 \\
\hline Min. & & 0.1 & 0.0 & 0.0 & 0.0 \\
\hline Median & & 3.0 & 1.7 & 1.0 & 1.6 \\
\hline Average & & 5.0 & 3.8 & 3.4 & 3.8 \\
\hline $\mathrm{N}$ & & 20 & 26 & 29 & 26 \\
\hline \multicolumn{6}{|l|}{ Domestic } \\
\hline 5 largest & & 73.4 & 68.2 & 71.4 & 71.9 \\
\hline 10 largest & & 92.9 & 84.5 & 86.9 & 87.9 \\
\hline 20 largest & & 100.0 & 97.4 & 98.4 & 99.1 \\
\hline Max. & & 20.2 & 18.4 & 21.9 & 25.0 \\
\hline Min. & & 0.5 & 0.4 & 0.1 & 0.0 \\
\hline Median & & 1.6 & 1.7 & 1.5 & 1.5 \\
\hline Average & & 5.3 & 4.0 & 3.8 & 3.8 \\
\hline $\mathrm{N}$ & & 19 & 25 & 26 & 26 \\
\hline
\end{tabular}

Source: ECB calculations. (C) globalcustody.net (2000-04) and reproduced from the full tables at www.globalcustody.net.

Note: This table is based on data supplied to globalcustody.net by individual global custodian banks. Some providers counted in the worldwide figures have not supplied a breakdown of their total figures. It should be noted that there is a degree of double-counting, with some assets being reported by banks acting in the capacity of sub-custodian and also by the corresponding global custodian.

instruments. Second, this development might also be driven by investment managers' and banks' increasing use of global custodians to substitute their own networks of local custodians. Third, in many countries pension schemes have been reformed, in that the state has diminished its role as the primary pension provider. This has led citizens to invest in defined contribution pensions and mutual funds. In turn, these pensions and mutual funds are usually serviced by their money managers and banks driving demand for clearing and custody services. Finally, it should also be noted that almost twice as many providers either reported data or entered the custody business in 2004 than was the case in 2000 . Hence, this increased number of custodian banks in operation in 2004 may make any comparisons over the sample period less obvious. However, when considering uniform groups of the largest custodian banks, the data supports high growth in global assets under custody. In a sub-sample of custodian banks, the data shows that the highest growth rates in the cross-border custody business were equally distributed across the 5, 10 and 20 largest groups. In contrast, domestic assets under custody showed only a very moderate increase, remaining at almost the same level throughout the period under consideration.

Table 6 presents the relative market share of worldwide assets under custody. Overall, the market for global custody services seems to be dominated by a very small number of global custody banks. The data indicates that, on average, two-thirds of global custody assets under custody are held by the five largest 
providers. The ratios from a smaller subsample of those banks that provided crossborder and domestic information confirm this trend and point towards a highly concentrated market structure. However, there are no clear signs of increasing concentration over the sample period.

Overall, it may be concluded that there has been substantial growth in overall custody activities with a relatively high degree of concentration indicating the large scale inherent in the global custody business. This trend has been most pronounced in cross-border activity, possibly as a result of increased globalisation and the integration of securities markets and infrastructures. However, there have been no clear signs of any increasing concentration on the global level over recent years.

\section{I.5 EUROPEANISATION OF THE USE AND MANAGEMENT OF COLLATERAL}

From a central bank perspective, securities settlement systems play a crucial role in the Eurosystem's collateral framework, as they provide the infrastructure that allows counterparties to transfer collateral to the Eurosystem. Therefore, the Eurosystem monitors the level of involvement of SSSs in Eurosystem credit operations. In the current framework, counterparties may transfer crossborder collateral to the Eurosystem via two main channels: the correspondent central banking model (CCBM) and links between SSSs. ${ }^{15} 16$

As Chart 3 shows, domestic collateral remains the major source of collateral, but there is a clear trend towards increasing cross-border use of collateral. In 2004 cross-border use of collateral became important in all euro area countries. Counterparties are increasingly tending to replace domestic collateral with foreign collateral. One reason for this development is the continued consolidation and integration of the euro area financial markets.

Under the CCBM, each central bank acts as custodian on behalf of any other central bank granting credit to its counterparties against collateral located in another country. Despite the fact that the CCBM was created as an interim model that would cease to operate as soon as the market had developed comprehensive and reliable alternatives, it represents the main instrument for mobilising cross-border collateral. As can be seen from Chart 3, the CCBM accounted for around $41 \%$ of total collateral in 2004.

SSSs can be linked to allow the cross-border transfer of assets between themselves. Once the securities are transferred through a link to another SSS, they can then be used through local procedures in the same way as any domestic collateral. Although the use of links between SSSs increased in absolute terms throughout 2004, their use remains limited and accounts for just over $7 \%$ of the total collateral provided to the Eurosystem, as shown in Chart 3 . In percentage terms, around $85 \%$ of crossborder collateral used in 2004 was via the CCBM, and the remaining $15 \%$ was via links.

Despite considerable improvements in the efficiency of CCBM processing procedures, as documented by the ECB monitoring exercise, ${ }^{17}$

15 The distinction between cross-border and domestic collateral has been blurred owing to ongoing consolidation and integration of the securities infrastructure; the country of the SSS where the securities are issued does not necessarily coincide with the country of the SSS where the operation is actually settled. As a result, in some cases assets reported as domestic are actually issued in an SSS of another country, while assets issued in an SSS in the country of the counterparty are actually settled in an SSS located in another country.

16 In addition, under the CCBM Agreement, the national central banks of Denmark, Sweden, the United Kingdom and the Netherlands were given the possibility of using their ICSD's account directly for euro market and international securities issued in that ICSD. As of July 2003, out-collateral was removed from the list of eligible collateral in Denmark and Sweden.

17 The main outcome of the CCBM monitoring exercise can be summarised as follows: (i) an average of approximately 29 minutes is needed by the NCBs to perform their internal CCBM procedures when acting as a home central bank (HCB) and 16 minutes when acting as a correspondent central bank (CCB). This is within the targeted benchmark and represents a significant improvement compared with the 1 hour 23 minutes and 52 minutes respectively recorded during the exercise carried out in 2002; (ii) approximately $83 \%$ of the instructions were within the targeted processing time $(78 \%$ for HCBs, $85 \%$ for $\mathrm{CCBs}$ ); (iii) the overall average end-to-end processing time for a CCBM transaction was 1 hour 42 minutes.
INTEGRATION OF

THE EUROPEAN SECURITIES

INDUSTRY:

DEFINITION AND DEVELOPMENTS 


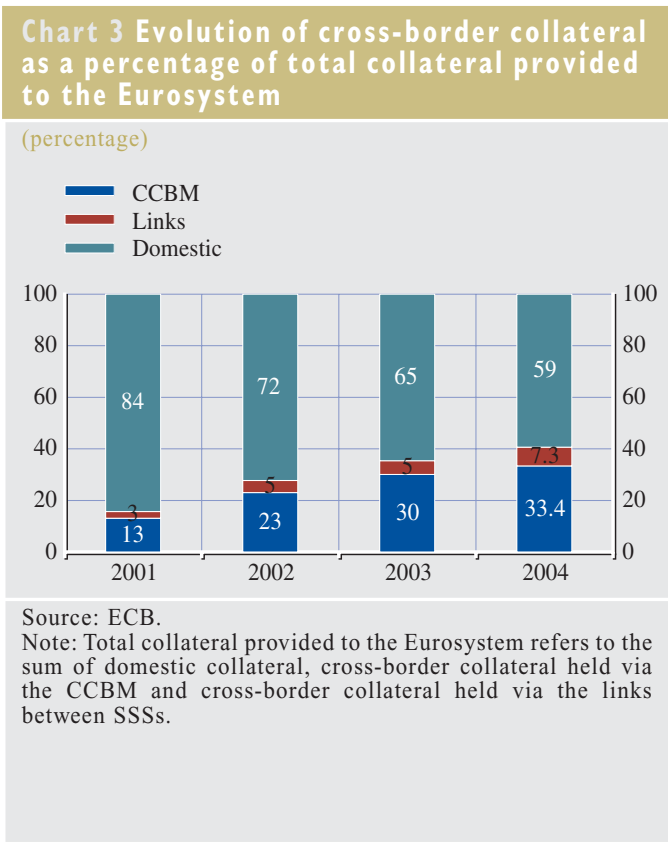

market participants expressed on various occasions the view that the CCBM is not yet able to meet all the needs of the banks. In line with the strong growth in several financial market segments (repo, securities lending, OTC derivatives, etc.), collateral assets are increasingly becoming a scarce resource which must be managed efficiently. Institutions have now realised that, because of activities in different currency zones, collateral management has become technically complex and inefficient. In this context market participants refer to the need to remove all 15 Giovannini barriers, not only in terms of the number of players, but also regarding technical requirements (e.g. settlement deadlines, corporate action rules, securities issuance practices), divergent tax procedures, and legal issues such as netting, conflicts of laws, and differences in securities laws.

Taking note of these trends in collateral business practices, the Eurosystem has invited market participants to rethink current arrangements and policy by focusing on possible future alternative cross-border collateral facilities.

\section{I.6 HOW MUCH INTEGRATION HAS BEEN ACHIEVED SO FAR?}

In the field of securities trading and posttrading infrastructures, the lack of well established price or quantitative indicators makes it harder to measure directly the degree of integration in the securities industry. However, in order to assess the current state of the infrastructure, it would appear useful to refer to the conditions that constitute financial integration as defined in Section 1.1 of this report, i.e. (i) the same set of rules, (ii) equal access to the market, and (iii) equal treatment in the market.

\section{SAME SET OF RULES}

Recalling Section 1.1, the market for a given set of financial instruments is defined as being integrated if the participants in that market face the same set of rules (i.e. the same technical requirements, the same price, the same legal framework, the same business practices, etc.). It was also pointed out that consolidation is an effective way of achieving integration. In fact, however, most EU Member States have traditionally developed their own coherent national securities market infrastructure. Nowadays, as shown in the above sections, some progress towards consolidation has been made in the securities infrastructure in the euro area, and this points towards a more networked and integrated securities landscape. The degree of integration and consolidation of the service providers involved and of the activities along the transaction value chain varies considerably. In the case of CCPs, the extent of mergers and the reduction in the number of legal entities acting as CCPs has been greater relative to the developments in the trading and settlement area. However, it should be noted that most of the mergers and consolidation initiatives at the European level have been purely legal mergers, i.e. the systems are still operating separate technical platforms. As already shown in previous sections, despite the single currency, the trading, clearing and settlement industry still shows a relatively high 
degree of fragmentation and insufficient harmonisation, with around 22 stock and derivatives exchanges, 8 CCPs, 18 local CSDs and 2 ICSDs active in the euro area, all operating on the basis of different technical procedures, prices, market practices and legal frameworks.

\section{EQUAL ACCESS}

According to the common understanding of financial integration, integration implies access for all users to the same services and financial instruments on the same conditions, regardless of the location of the user or provider. In the area of securities systems, there are national restrictions in some EU Member States on the location of clearing and settlement and on the location of securities. These restrictions can limit choices for issuers when placing their securities and/or make it more complicated to hold and settle those securities in Member States other than the place of issuance. As such, they effectively limit free access to securities systems. For example, there is the requirement in some Member States that issues in listed securities be deposited exclusively locally and/or that transactions in such securities be settled exclusively on the books of the local settlement system. Moreover, even if there are no formal restrictions on access, it is effectively misleading to speak of equal access for all investors to all systems. Investors typically have direct access only to a single (i.e. their national) system, as the cost of direct membership is high. Investors rarely access a foreign system directly and typically need to use intermediaries to this end, i.e. a local agent, an international CSD or a global custodian. Less often, investors use links between their local CSD and the foreign CSD. Thus, crossborder clearing and settlement of a securities transaction typically involves intermediaries in addition to the buyer and seller. The use of intermediaries when interacting with different systems increases the risk and cost for the cross-border investor and this cost rises with the number of different clearing and settlement systems that must be accessed. The lack of integration may thus lead to a distortion in investment decisions and the allocation of capital.

\section{EQUAL TREATMENT}

Securities systems do not normally discriminate on the basis of nationality. Put differently, there is equal treatment of participants within a system. However, there is no equal treatment across systems. Indeed, owing to the multiplicity of securities trading, clearing and settlement systems not only in the euro area but also in Europe, pan-European users are required to access (directly or indirectly) many national systems that provide very different types of services, have different technical requirements/market practices (settlement periods, rules relating to corporate actions and issuance practice, etc.), and operate within different tax and legal frameworks. These significant national differences in clearing and settlement procedures are a result of insufficient integration. They create barriers to efficient cross-border trading, clearing and settlement services to the extent that they impose additional risk and cost on investors who operate in more than one national market. The additional cost that is associated with this fragmented infrastructure represents a major limitation on the scope for cross-border securities trading, clearing and settlement business.

In conclusion, the consolidation process in the trading and post-trading infrastructure has hitherto not encouraged integration in terms of the singleness of the market, equal access and equal treatment. Although most market providers acknowledge the importance of panEuropean systems, true integration also in technical terms is not progressing very fast and will still take some considerable time to be completed. As yet it is still unclear what degree and what model of integration will eventually prevail in the euro area. Indeed, there are a number of barriers to consolidation, including
| INTEGRATION OF THE EUROPEAN SECURITIES INDUSTRY: DEFINITION AND DEVELOPMENTS 
legal difficulties, a lack of standardisation, and vested interests. However, it can be anticipated that there will be continued and increased merger activities, alliances, and other forms of cooperation between and interoperability of securities exchanges and clearing and settlement providers in the near term. Interoperability enables cooperation between infrastructure providers at a technical level through agreement on common processes, methods, communication practices and protocols, and networks. A common feature of all of these approaches is that they could help to improve the efficiency of the systems.

\section{THE ECB'S SPECIFIC INTEREST IN THE INTEGRATION OF THE EUROPEAN SECURITIES INFRASTRUCTURE}

Despite the existence of the single currency, the securities infrastructure in the euro area is highly fragmented, with a large number of national exchanges, central counterparty clearing houses and central securities depositories. ${ }^{18}$ No other currency area has ever had to cope with such a fragmented securities infrastructure, the result of the fact that the euro area has inherited the infrastructures of its member countries. It is clear, therefore, that greater consolidation and/or competition is needed. The current state of the European infrastructure also needs to be reshaped. Traditionally, countries (which would typically be the same as currency areas) would develop their own coherent "domestic" infrastructure for securities trading, clearing and settlement. The ECB has a strong interest in the development of a similarly coherent and integrated infrastructure for the euro area, and there are several reasons for this.

\section{I MONETARY POLICY AND THE FUNCTIONING OF PAYMENT SYSTEMS}

The Eurosystem aims to protect itself from incurring losses in its credit operations. Consequently, all Eurosystem liquidity- providing operations are based on underlying assets, either in the form of the transfer of ownership or in the form of a pledge granted over relevant assets. ${ }^{19}$ For the collateralisation of its credit operations, the Eurosystem makes use of securities settlement systems that fulfil certain standards established by the ECB. ${ }^{20} \mathrm{In}$ the event of malfunctions and disturbances in the settlement process as a result of insufficient integration, the provision of liquidity could be affected. For example, assets that are eligible as collateral for Eurosystem credit operations must be usable in a cross-border context in the entire euro area. However, fragmentation of the securities infrastructure complicates the cross-border use of collateral, as it requires specific arrangements, such as links between settlement systems, to overcome the fragmentation. The degree of integration is thus important in determining how (cost)effective the transmission of monetary policy will be in practice.

Since all central bank credit operations including intraday credit used for payment systems purposes - need to be fully collateralised, inefficiencies in the clearing and settlement process that result from the fragmentation of the securities infrastructure will also affect the provision of intraday liquidity in the TARGET system. In fact, TARGET would be blocked if securities were not delivered to the Eurosystem on time. Furthermore, well integrated securities clearing and settlement systems are important for payment systems, because most securities transactions typically also involve the settlement of funds. As a result, banks include the payment flows stemming from securities settlement in their intraday liquidity

18 See Section 3 for further details

19 Article 18.1 of the Statute of the ESCB allows the ECB and the national central banks to transact in financial markets by buying and selling underlying assets outright or under repurchase agreements, and requires all Eurosystem credit operations to be based on adequate collateral.

20 The standards for the use of securities settlement systems in Eurosystem credit operations are available on the ECB's website at http://www.ecb.int/pub/pdf/othemi/sssstandards1998en.pdf 
management. If these funds are not delivered, or are not delivered on time, payment systems could become gridlocked. The link between securities settlement systems and payment systems has been further strengthened through the development of delivery-versus-payment (DvP) facilities. DvP has, on the one hand, reduced credit risk but has, on the other hand, also increased the liquidity risks which may arise in the event of a failure to deliver securities, in particular when settlement occurs in real-time gross settlement (RTGS) systems.

Finally, the ECB has an interest in ensuring a level playing field and the equal treatment of all its counterparties when conducting credit operations. For example, it should not make a difference to a Finnish commercial bank whether it uses Finnish or French securities as collateral to obtain central bank credit. In more general terms, integration enables service users to pay the same price for the same product or service, regardless of their location. The costs of clearing and settlement should not distort investment decisions. Irrespective of whether a final investor in Finland, for instance, buys or sells a security issued in Finland or in France, there should not be a difference in terms of clearing and settlement costs.

\subsection{FINANCIAL STABILITY}

Securities clearing and settlement arrangements lie at the core of all financial markets and are indispensable if those markets are to function properly. A major malfunction in a securities clearing and settlement system could undermine the stability of the financial markets and, ultimately, affect public confidence in the currency. As the degree of integration of the securities infrastructure can have an impact on financial stability, central banks also have an interest in the integration of the securities infrastructure from a financial stability perspective.

For example, a market structure which is composed of several clearing and settlement systems implies less risk concentration than a more consolidated structure and could offer some protection from systemic risk. This is because financial stability can be negatively affected by the activities of the settlement system itself. In the case of financial markets where the settlement business is centred around a very small number of large custodians or a single central securities depository, disruptions in the settlement process may affect the financial markets as a whole, owing to the systemic importance of such systems. Central banks are therefore very much concerned with the operational reliability and the financial soundness of the settlement system in order to be sure that the system is functioning properly. For the same reason, central banks have an interest in the legal frameworks and the communications networks that settlement systems are built on and make use of.

In a decentralised and less integrated market structure, protection from systemic risk declines with the degree of inter-linkage between the various systems, because the probability of contagion effects increases accordingly. Clearing and settlement systems are typical examples of network economies and are thus particularly prone to contagion effects. For example, participants are confronted with the risk that other participants will not settle obligations when due (liquidity risk) or at any time thereafter (credit risk). In such a case, the inability of one participant to meet its obligation may cause other participants to fail as well. In systems with multilateral netting, if a participant fails to settle, some or all of the provisional transfers involving that participant are deleted from the system and the settlement obligations of the remaining participants have to be recalculated. This may substantially delay the settlement of all transactions and thus give rise to contagion effects that could disrupt the financial market. Moreover, linking systems with one another can create a number of potential technical and legal problems that do not exist in a consolidated structure. For example, an operational difficulty in a link between two systems in a network can itself
2 THE ECB'S SPECIFIC INTEREST IN THE INTEGRATION OF THE EUROPEAN SECURITIES INFRASTRUCTURE 
create contagion effects by resulting in a failure to complete a settlement across the link. Such contagion could cause significant liquidity or credit problems and, as a result, threaten the stability of the financial system as a whole.

Central banks have particular worries with regard to the consolidation of central counterparty clearing houses. ${ }^{21}$ By nature, central counterparties manage and concentrate the credit risk of the marketplaces they serve. The consequences of risk management failures would therefore be particularly severe and would increase with the degree of consolidation between central counterparties. This is even more serious as there is a risk that the market will assume that central banks will bail out an ailing central counterparty, given the potential systemic effects of the failure of a major clearing house. This expectation of public intervention in a crisis can constitute an obstacle to the development of sound and effective risk management measures by the central counterparty ("moral hazard"). Moreover, the risk management framework that a central counterparty clearing house operates may imply that losses are shared among its participants. Such externalisation of losses may lead participants to trade imprudently and take excessive risks. Integration also affects competition between central counterparties. Competition is important, as it entails a risk that such service providers may try to improve competitiveness by applying more lenient risk management standards. Moreover, clearing houses typically undertake activities which support the securities settlement process, such as the matching and netting of trade orders. Problems on the clearing side could therefore spill over to the settlement side. Finally, if integration leads to cross-product clearing and/or crosscurrency clearing, there is a risk of contagion from one market to another in the event of the failure of a central counterparty.

\subsection{EFFICIENCY}

As trading, clearing and settlement are at the core of financial markets, inefficiencies in these processes have serious consequences. When trading, clearing and settlement are too costly or complex as a result of insufficient integration, financial transactions are discouraged, and this will have a negative effect on the allocation of capital, risk sharing across agents and economic growth. In other words, the integration of the securities infrastructure is a necessary condition for the integration of the financial market that it serves. Given its interest in financial market integration, the ECB therefore also has an interest in the integration of the securities infrastructure. From a user perspective, the efficiency of settlement procedures is particularly important for the provision of intraday credit and for repo transactions.

In general, the efficiency of clearing and settlement arrangements is an important public policy objective for securities regulators and central banks alike. There are several examples of public initiatives aimed at enhancing efficiency. At G10 level, the CPSS/IOSCO Recommendations for Securities Settlement Systems are intended to promote the implementation of measures that enhance not only the safety, but also the efficiency of securities settlement systems. Recommendation 15 specifically addresses efficiency requirements. ${ }^{22}$ The CPSS/IOSCO Recommendations for Central Counterparties also contain a Recommendation that addresses efficiency. ${ }^{23}$ In the European context, the ESCB/CESR Standards for Securities Clearing and Settlement in the EU explicitly identify the efficient functioning of securities trading

21 See also the "Eurosystem policy line with regard to consolidation in central counterparty clearing", available on the ECB's website at http://www.ecb.int/press/pr/date/2001/ html/pr010927_2.en.html.

22 See CPSS/IOSCO Recommendations for Securities Settlement Systems, November 2001, Chapter 2 .

23 See CPSS/IOSCO Recommendations for Central Counterparties, November 2004, Recommendation 12. 
markets and the cost-effective settlement of their transactions as an objective of the Standards. ${ }^{24}$ Finally, in its "Communication on clearing and settlement" released on 28 April 2004, the European Commission outlines the action that it intends to take in order to improve EU clearing and settlement arrangements and identifies the efficiency of the European securities infrastructure as a key objective.

Improvements in integration for the sake of greater cost-effectiveness are particularly important in the European context. As shown in Section 1.3, there is strong evidence to suggest the presence of inefficiencies and system complexities in international trading, clearing and settlement. It is therefore important that the discussion regarding the benefits of the integration of the EU's financial infrastructure should also consider all costs and services involved in the transaction value chain. These include not only direct trading costs arising from trading, brokerage and market impact at the exchange level, but also costs incurred in post-trading activities.

Fragmentation of the European securities infrastructure is a problem because the security, the buyer and the seller may not be linked to the same settlement system. In this case, some kind of intermediation is needed, either through a custodian or through another settlement system. Any form of intermediation, however, is a potential source of cost for users. As a result, Europeans spend more on capital to service those transactions, and that cost ends up with investors. The cost has to be recovered somewhere and so goods and services are more expensive and less competitive internationally. Although the total cost to the European economy is hard to calculate, it is likely to be significant and can be effectively reduced only by further improvements in the integration process. ${ }^{25}$

Finally, by ensuring the efficiency of the financial services provided in its currency area, the ECB also enhances the position of the euro area as a competitive international financial centre. The integration and consolidation of the securities infrastructure clearly plays a key role in this regard. Greater consolidation has some advantages over more decentralised structures. For example, it reduces unit costs by fully capturing economies of scale and network externalities. Moreover, larger service providers typically have the financial strength to invest in new - and sometimes costly technologies, which may increase efficiency and reduce risk in the clearing and settlement business. Finally, a smaller number of providers of clearing and settlement services may facilitate the harmonisation of technical standards and market conventions for the markets covered.

\section{INDUSTRY STRUCTURE, PERFORMANCE AND STABILITY}

A number of theoretical and descriptive studies have been published recently addressing various aspects of securities market infrastructure integration, market interlinkages, pricing and competition. A brief review of each of these is appropriate here. ${ }^{26}$

\section{I REVIEW OF THEORETICAL AND POLICY- ORIENTED STUDIES}

One of the first contributions in this area comes from Giddy, Saunders and Walter (1996). They analyse the generic organisational structure of the European clearing and settlement industry from the perspective of the users of these services. Balancing four alternative market models, they conclude that economies of

24 See ESCB/CESR Standards for Securities Clearing and Settlement in the EU, October 2004, Introduction.

25 A number of empirical studies have found significant differences in terms of cost for clearing and settlement within the EU and between the EU and the United States (e.g. Schmiedel et al., 2002; Van Cayseele and Wuyts, 2005). See also Section 3.2 for a comprehensive overview of selected cost studies.

26 A comprehensive description and overview of the European post-trade market structure, its mechanisms and its relevant market participants are presented in Deutsche Börse Group (2005).
3 INDUSTRY

STRUCTURE,

PERFORMANCE

AND STABILITY 
conglomeration or critical mass are likely to favour centralisation and consolidation of European clearing and settlement systems.

Taking up this line of reasoning, Tapking and Yang (2004) analyse the implications for welfare of two different types of consolidation in the securities trading and settlement industry - mergers of an exchange with a CSD (vertical integration) and mergers of two CSDs (horizontal integration). Both types of integration increase economic welfare compared with no consolidation, but the welfare improvement is greater in the case of a horizontal merger. This result is dependent on two crucial assumptions made in the paper. Firstly, it is assumed that investors have strong preferences for securities issued abroad. If investors instead preferred home securities, vertical integration would outperform horizontal integration. Secondly, it is assumed that all exchanges are bound to settle in a given CSD and cannot choose between different CSDs. The results of their analysis could change if this assumption was not used. Issues for further research in this model could be to consider a policy that would force the CSDs to charge a price of zero for the transfer of securities through links, as well as to address the issue of whether market forces lead to the optimal form of consolidation.

Other theoretical papers analyse the role of vertical silos in securities market organisation for efficient horizontal consolidation between components of the silo, i.e. exchanges and back-office operations such as clearing and settlement. Koeppl and Monnet (2004) outline a model where two firms that operate a silo can realise gains from a merger. These gains arise from increases in overall demand as well as cost savings. Here, the authors assume that the costs for settling transactions potentially differ across firms and are private information. Using tools from mechanism design, the paper shows that it is impossible to achieve an efficient merger, i.e. a merger where, after the merger, settlement takes place at the lowest cost. This is due to the fact that it is too costly to induce the firms to reveal their true settlement costs. The second part of the paper presents two solutions to this. First, a sufficiently high subsidy can realise all benefits from lower settlement costs, but is costly itself. Second, the authors offer a less costly market solution. They show that firms can achieve an efficient merger by each outsourcing their own settlement operations to an agent. Competition between the agents for settling all trades of the merged exchange then reveals the true cost of settlement. Hence, they argue that fostering competition and open access to securities settlement systems may be required to enhance the efficiency of securities markets.

Moreover, Holthausen and Tapking (2004) describe price competition between two settlement service providers, a national CSD and a custodian bank. In their model, the CSD sets two prices, customers have to pay a price $q$ for having a securities account with the CSD and another price $p$ for settling a transaction on that account. The custodian bank does the same. There are many other banks that have to trade a security issued into the CSD. Each of these "investor banks" trades once. To settle its transaction, each investor bank needs to have a security either with the CSD directly or with the custodian bank. The decision of an investor bank regarding which of the two service providers should be chosen depends on the prices and on the preferences of the investor bank for the heterogeneous services offered by the CSD and the custodian bank. The custodian bank itself needs to have a securities account with the CSD to settle transactions between an investor bank with an account with the CSD and another investor bank with an account with the custodian bank. It is shown that the CSD can raise the custodian bank's costs in a subtle way. As mentioned above, each investor bank trades only once, i.e. investor banks with an account with the CSD have to pay the price $q$ once and also the price $p$ once to the CSD. The custodian bank also has to pay $q$ to the CSD once. However, it has to pay the price $p$ many times. The CSD can raise the custodian bank's costs without changing the costs of its investor 
bank customers by increasing $p$ and decreasing $q$ by the same amount. It is shown that, using this strategy, the CSD can achieve a higher market share than the custodian bank. However, it is also shown that, owing to network externalities, the CSD's equilibrium market share is not necessarily higher than socially optimal.

Considering a variant of the Holthausen and Tapking (2004) paper, Rochet (2004) addresses potential trade-offs in the choice of industry structure. In other words, the paper analyses whether market forces will find a "final" structure of the securities clearing and settlement infrastructure industry that also leads to the social optimum. From a welfare point of view, the paper compares the two situations when the CSD is independent from the custodian banks (CSD model) and when a CSD merges with a custodian bank (ICSD model). The author shows that vertical integration might have a positive impact on efficiency through a decrease in the variable transaction fees and by a reduction of the number of intermediaries along the transaction chain. However, vertical integration of a custodian into a CSD might also coincide with a decrease in competition for complementary banking services, possibly leading to an increase in the fixed fees charged to investors. Balancing the overall effects, the author concludes that vertical integration seems to favour broker/dealers and tends to penalise retail investors. However, no conclusion is drawn on the net impact on social welfare.

As another means of financial market integration, many CSDs have established bilateral links to facilitate the settlement of cross-border transactions. Kauko (2004) presents a theoretical model of links between securities settlement systems. Because pooling payments can help to use liquidity efficiently, issuers prefer settlement systems in which a large number of securities are issued. If the CSDs establish a mutual link that enables investors to make transactions with foreign securities, cost savings can be achieved via the increased liquidity induced. The main focus of the paper, however, is on the competition between two national CSDs and the impact of a securities link on this competition. The authors conclude that if policy-makers want to enhance the international integration of equity markets, they should focus on eliminating the fundamental causes of the obstacles to crossborder settlement.

Although the opening of mutual links between CSDs involves relatively high investment costs, the use of these links to channel crossborder transactions has generally been rather limited. Against this background, Kauko (2003) provides an explanation for why links between CSDs are set up but not often used. In the first part of the paper, it is assumed that a CSD first sets a price for settling primary market transactions. Then investors and issuers agree on primary market transactions and these transactions are settled. Next, the CSD sets a price for settling secondary market transactions. Finally, secondary market transactions are agreed upon and settled. It is assumed that primary market transactions and secondary market transactions are complementary goods, i.e. there is little benefit from primary market transactions without secondary market transactions. Knowing this, the CSD will set a relatively high price for secondary market transactions. In expectation of this, the investors and issuers trade on the primary market only if the primary market settlement price is very low. In the second part of the paper, it is assumed that the CSD can set up a link to another CSD so that secondary market transactions can also be settled in the other CSD. In other words, if the issuer CSD chooses a very high secondary market price, settlement will take place in the other CSD. Hence, the issuer CSD can commit on lower secondary market prices by setting up the link. It can now choose a relatively high primary market price and increase its profit. However, the link is hardly used.

Serifsoy and Weiss (2003) describe three alternative systems for the securities
3 INDUSTRY

STRUCTURE,

PERFORMANCE

AND STABILITY 
transaction industry. According to their framework, a model of contestable monopolies obviously dominates the others, but is prone to instability and might deviate to an inefficient system. Malkamäki and Topi (1999) argue that the increased contestability of financial markets opens the way for a completely new situation where economies of scale and network effects enable new systems to challenge existing exchanges and settlement systems. Van Cayseele (2004) also argues along these lines, favouring a contestable quasi-monopoly configuration of the future clearing and settlement industry. He also advocates competent public authorities to carefully address antitrust issues that might emerge from strong concentration.

In his policy-oriented paper, Milne (2002) proposes access pricing regulation of book transfers and the communication of instructions for corporate actions in order to stimulate European market integration for the issue and trading of securities. He concludes that the book-entry function and a few related services are a natural monopoly, at least at issuer level. On the other hand, CSDs offer a wide range of services that can be offered by competing firms if the CSDs do not prevent competition by abusing their control over the book-entry system. He argues that certain core functions should be left to a monopoly whereas competition should be introduced in all other clearing and settlement related services, preferably at the European level. A regulation on terms and pricing of access could be implemented to prevent abuse of the CSDs' monopoly position in potentially competitive operations.

In a manner related to the reasoning of Milne (2002), Knieps (2004) argues that clearing and settlement reveal characteristics of competitive value-added telecommunications services and therefore do not justify ex ante market power regulation. The precondition for competition on the markets for clearing and settlement is non-discriminatory access to the complementary technical regulatory function the notary function.

Given the fact that cross-border settlement is often more complex and costly than domestic settlement, Leinonen (2003) proposes infrastructural solutions and specific methods (e.g. an international custody account number system and DVP-codes for matching) to simplify current international processing systems. He concludes that the proposed new infrastructural solutions would bring benefits to users, mainly in terms of faster or immediate delivery, less risk, lower processing costs, more competition and more efficient processing of corporate actions. However, implementation at the international level will require coordination and engagement by key players.

\subsection{COST STUDIES OF SECURITIES CLEARING AND SETTLEMENT: SURVEY AND STYLISED FACTS}

It is only recently that a few studies of the cost of securities clearing and settlement have been published. Table 7 offers a selected survey of the existing literature on clearing and settlement costs in Europe and the United States. The table characterises the studies with regard to methodology, sample size, coverage, period and findings, as well as data sources. As can be seen, the studies surveyed differ in several respects.

With respect to the methodology, most of the studies cited in Table 7 follow a descriptive approach using cost and revenue ratio comparisons of average standard trades and settlement transactions. Clearstream (2002) estimates incremental costs for retail and wholesale transactions of foreign and domestic shares. Using a top-down approach, the studies of Lannoo and Levin (2001) and London Stock Exchange/OXERA (2002) analyse operating cost and revenue structures of clearing and settlement organisations in the European Union. Through a bottom-up analysis of different pricing and charging regimes, NERA 


\begin{tabular}{|c|c|c|c|c|c|c|}
\hline Authors/study & Methodology & Period & $\begin{array}{l}\text { Geographical } \\
\text { scope }\end{array}$ & $\begin{array}{l}\text { Sample } \\
\text { countries }\end{array}$ & Results & Data source \\
\hline AFTI (2002) & $\begin{array}{l}\text { Descriptive, } \\
\text { ratios, cost of } \\
\text { standard trade }\end{array}$ & & EEA vs. US & $\begin{array}{l}\mathrm{CH}, \mathrm{DE}, \\
\text { FR, IT, } \\
\text { UK, US }\end{array}$ & $\begin{array}{l}\text { Trading costs in EU and United States: EUR 70- } \\
115 \text { per trade; no significant difference in broker } \\
\text { fees for domestic or foreign trades; custodians } \\
\text { prices for domestic trades at EUR 10; cross- } \\
\text { border custodian costs } 2.5-4 \text { times higher than } \\
\text { domestic, but similar in EU and United States. }\end{array}$ & $\begin{array}{l}\text { AFTI, institutional } \\
\text { investors }\end{array}$ \\
\hline $\begin{array}{l}\text { Clearstream } \\
(2002)\end{array}$ & $\begin{array}{l}\text { Descriptive, } \\
\text { cost of } \\
\text { standard trade, } \\
\text { intra vs. } \\
\text { cross-system }\end{array}$ & 2001 & Local; DE & $\mathrm{DE}$ & $\begin{array}{l}\text { Total cost of wholesale trade } 30 \% \text { higher for } \\
\text { foreign than domestic and } 150 \% \text { higher for retail } \\
\text { trades; EUR } 4.3 \text { billion of incremental costs for } \\
\text { cross-border trading and equity holdings. }\end{array}$ & $\begin{array}{l}\text { Deutsche Börse } \\
\text { Group, industry } \\
\text { interviews }\end{array}$ \\
\hline $\begin{array}{l}\text { Lannoo and } \\
\text { Levin (2001) }\end{array}$ & $\begin{array}{l}\text { Descriptive, } \\
\text { ratios, cost, } \\
\text { revenues }\end{array}$ & 2000 & EU vs. US & $\begin{array}{l}\text { DK, DE, } \\
\text { ES, FR, } \\
\text { GR, IT, } \\
\text { LU, PT, } \\
\text { SE, UK, } \\
\text { US }\end{array}$ & $\begin{array}{l}\text { Settlement cost in EU is seven times higher } \\
\text { than in United States. EU unit operating income } \\
1.86 \text { times higher than in United States; United } \\
\text { States operating margin much higher than in EU; } \\
\text { domestic settlement as cost-efficient as in United } \\
\text { States, but cross-border settlement much higher } \\
\text { in EU. }\end{array}$ & $\begin{array}{l}\text { Annual reports and } \\
\text { financial statements } \\
\text { 2000, ECB Blue } \\
\text { Book }\end{array}$ \\
\hline $\begin{array}{l}\text { London Stock } \\
\text { Exchange/ } \\
\text { OXERA } \\
\text { (2002) }\end{array}$ & $\begin{array}{l}\text { Descriptive, } \\
\text { top-down, } \\
\text { cost and } \\
\text { revenues } \\
\text { ratios, } \\
\text { pre-netting }\end{array}$ & 2000 & EEA vs. US & $\begin{array}{l}\text { BE, CH, } \\
\text { DE, DK, } \\
\text { ES, FR, } \\
\text { GR, IT, } \\
\text { LU, NL, } \\
\text { NO, PT, } \\
\text { SE, UK, } \\
\text { US }\end{array}$ & $\begin{array}{l}\text { Cost savings potential of } 81 \% \text { (EUR } 1.6 \text { billion) } \\
\text { if single EU system; United States } 5.5 \mathrm{~m} \text { vs. } \\
\text { EU } 2.8 \mathrm{~m} \text { daily transactions at } 2 / 5 \text { of total costs } \\
\text { to end-users; six times higher clearing and } \\
\text { settlement costs per transaction in EU vis-à-vis } \\
\text { United States; differences in end-user costs due } \\
\text { to higher operating costs and high average profit } \\
\text { margin in EU vis-à-vis United States. }\end{array}$ & $\begin{array}{l}\text { Annual reports and } \\
\text { financial statements } \\
2000\end{array}$ \\
\hline NERA (2004) & $\begin{array}{l}\text { Descriptive, } \\
\text { fees, } \\
\text { bottom-up }\end{array}$ & & EEA vs. US & $\begin{array}{l}\text { BE, CH, } \\
\text { DE, IT, } \\
\text { NL, UK, } \\
\text { US }\end{array}$ & $\begin{array}{l}\text { High clearing and settlement cost difference } \\
\text { between EU and United States; EUR } 0.10 \text { in } \\
\text { United States vs. EUR } 0.35-0.80 \text { in EU per } \\
\text { on-exchange domestic equity transaction; } \\
\text { EUR } 0.57-35 \text { for EU cross-border settlement. }\end{array}$ & $\begin{array}{l}\text { Companies' tariff } \\
\text { schedules, industry } \\
\text { interviews }\end{array}$ \\
\hline SEC (1975) & $\begin{array}{l}\text { Descriptive, } \\
\text { cost ratios }\end{array}$ & 1975 & Local; US & US & $\begin{array}{l}\text { Economies of scale according to three models: } \\
\text { (1) linkages of seven settlement systems, } 9.6 \% \\
\text { potential cost saving; (2) maintain and link three } \\
\text { systems, } 32.7 \% \text { cost reduction; (3) only one } \\
\text { settlement system, } 63.5 \% \text { cost saving. }\end{array}$ & $\begin{array}{l}\text { Survey of seven } \\
\text { C\&S institutions; } \\
\text { cross-section } \\
\text { of } 63 \text { brokerage } \\
\text { companies }\end{array}$ \\
\hline $\begin{array}{l}\text { Schmiedel, } \\
\text { Malkamäki, } \\
\text { Tarkka (2002) }\end{array}$ & $\begin{array}{l}\text { Regression, } \\
\text { economies } \\
\text { of scale, cost } \\
\text { and revenues } \\
\text { ratios and } \\
\text { functions }\end{array}$ & 1993-2000 & $\begin{array}{l}\text { Global; } \\
\text { EEA vs. US }\end{array}$ & $\begin{array}{l}\text { BE, CA, } \\
\text { CH, DE, } \\
\text { DK, FI, } \\
\text { FR, HK, } \\
\text { JP, IT, } \\
\text { LU, NL, } \\
\text { NO, SE, } \\
\text { UK, US }\end{array}$ & $\begin{array}{l}\text { Economies of scale in EU; high unit cost saving } \\
\text { potential of } 1 / 3 \text {; high profit margins in EU vis-à- } \\
\text { vis United States; EU domestic settlement cost } \\
\text { on average at par with United States benchmark; } \\
\text { EU cross-border settlement much higher than } \\
\text { domestic; cost reduction due to technological } \\
\text { development }\end{array}$ & $\begin{array}{l}\text { Annual reports and } \\
\text { financial statements } \\
\text { 1993-2000; ECB } \\
\text { Blue Book, BIS } \\
\text { Payment Statistics, } \\
\text { IMF }\end{array}$ \\
\hline $\begin{array}{l}\text { Van Cayseele } \\
\text { and Wuyts } \\
\text { (2005) }\end{array}$ & $\begin{array}{l}\text { Regression, } \\
\text { economies } \\
\text { of scale and } \\
\text { scope }\end{array}$ & $1997-2003$ & EEA & $\begin{array}{l}\text { CH, DK, } \\
\text { GR, IT, } \\
\text { PT, NO, } \\
\text { SE, UK }\end{array}$ & $\begin{array}{l}\text { Economies of scale and scope in EU; potential } \\
\text { unit cost savings of } 50 \% \text {. }\end{array}$ & $\begin{array}{l}\text { Annual reports and } \\
\text { financial statements } \\
\text { 1997-2003; ECB } \\
\text { Blue Book, BIS } \\
\text { Payment Statistics }\end{array}$ \\
\hline
\end{tabular}

(2004) reveals large variations between the direct costs of clearing and settlement in the United States and Europe. Schmiedel et al. (2002) is the first empirical study that goes beyond simple tariff and cost comparisons. In their paper, the authors estimate alternative multi-product cost functions of settlement providers and quantify the existence and cost savings potential through economies of scale in European depository and settlement systems. In line with the work of Schmiedel et al. (2002), van Cayseele and Wuyts (2005) confirm evidence of large economies of scale in the clearing and settlement industry. They also 
reveal that separating certain activities from others can only be done at the cost of efficiency.

The country selection and sample period also vary across studies. The choice depends essentially on the availability of relevant cost data and the pricing schemes of the organisations under scrutiny. The majority of the studies focus on cross-country comparisons of securities clearing and settlement providers in the EU and the United States (AFTI, 2002; Lannoo and Levin, 2001; London Stock Exchange/OXERA, 2002; NERA, 2004; Schmiedel et al., 2002). While most studies concentrate on a one-year sample period (Clearstream, 2001; Lannoo and Levin, 2001; London Stock Exchange/OXERA, 2002), Schmiedel et al. (2002) covers an eight-year sample period, allowing an assessment to be made of the cost-effectiveness of and technological developments in depository and settlement systems over time. Van Cayseele and Wuyts (2005) include data for recent years.

Despite their differences, most of the studies come to similar conclusions with respect to the relatively large difference in clearing and settlement costs between the EU and the United States. There is also consensus with regard to the potential cost savings for cross-border settlement in the EU. Some studies suggest that cross-border clearing and settlement costs are between four and seven times higher in the EU than in the United States (AFTI, 2002; and Lannoo and Levin, 2001). Clearstream (2001) finds that the total cost of foreign wholesale transactions is 30 percent higher than domestic wholesale transactions, while foreign retail trades are 150 percent more costly than domestic retail transactions. ${ }^{27}$ Other studies with a broader scope estimate that the potential average cost saving would range from onethird (Schmiedel et al., 2002) and one half (Van Cayseele and Wuyts, 2005) to more than twothirds (London Stock Exchange/OXERA, 2002) were Europe to adopt a single system. The magnitude of these latter findings is roughly in line with the results of an earlier study of the US market (SEC, 1975), where the estimated cost savings through the implementation of the DTCC were greatest (64\%) when moving to a single, properly regulated settlement system.

Less agreement exists among the studies with regard to the optimal treatment of different cost categories, levels of data aggregation, settlement modes, locations of settlement, methods of payment, specifications of transaction data, and other measurement problems. Lannoo and Levin (2001) and London Stock Exchange/OXERA (2002) acknowledge the sensitivity of their approaches to the use of pre- and post-netting arrangements. Moreover, ICSDs differ in many respects from their domestic counterparts in terms of the scope of instruments, environments and services provided. Therefore, the inclusion or exclusion of ICSDs also has a significant impact on the robustness and comparability of the data (Schmiedel et al., 2002). Another drawback is that a comparison of direct cost tends to underestimate the total cost of a cross-border settlement because a large proportion of the total costs of a transaction stems from indirect costs such as back-office expenses and from the use of the additional intermediaries involved in the transaction value chain (London Stock Exchange/OXERA, 2002). Alternatively, NERA (2004) examines the cost of clearing and settlement in Europe and the United States using a "bottom-up" analysis based on the tariff schedules of clearing and settlement providers. This approach obviously allows a comparison to be made of the charges imposed for specific services by different service providers. However, the main limitation is that it does not enable any judgement to be made of the total cost in Europe or in the United States. The pricing schemes and tariffs cross the value

\footnotetext{
27 For further definitions and explanations of the terms "domestic", as opposed to "foreign", and "retail", as opposed to "wholesale", see Clearstream (2001).
} 
chain differ in many respects (e.g. volume, sliding schemes, settlement fines), making adequate cross-system and cross-service comparisons very complex.

\subsection{TECHNICAL EFFICIENCY VERSUS FINANCIAL STABILITY}

The European securities trading, clearing and settlement infrastructure has been changing rapidly in many ways and consolidation of the securities industry is likely to continue in the foreseeable future. The process of consolidation will probably entail gains in technical efficiency in the trading, clearing and settlement of cross-border securities transactions in Europe. Further integration might also lead either to a reduction, on average, in the number of different systems that are involved or to a harmonisation of procedures, thereby ensuring and increasing inter-linkages between and the interoperability of various systems. Consequently, fewer instructions and less information will have to be transferred between the systems, which may reduce the risk of failures and, thereby, systemic risk.

In contrast, consolidation also has the potential to concentrate activities within a few large systems. Any failure of these systems might lead to severe disruptions of the securities markets. ${ }^{28}$ Hence, further progress in market integration and consolidation in the securities market infrastructure may create market conditions in which potential disturbances and disruptions could generate contagion and systemic failures. Against this background, it is essential to monitor carefully the risk associated with the various benefits of diversification and integration.

\section{SHAPING THE INFRASTRUCTURE FOR THE EURO}

Despite the introduction of the single currency, consolidation and integration of the euro area securities trading, clearing and settlement industry has, so far, progressed at a rather limited pace, and there are still a number of barriers to integration in place. In order to achieve an efficient and sound securities clearing and settlement infrastructure, structured cooperation is required between the private and public parties active in the field of securities clearing and settlement. The ECB actively participates in various types of initiatives and is involved in different capacities with the aim of promoting the integration of the European financial infrastructure. In this way, the ECB contributes to the policies providing for a sound and efficient European and global architecture for the clearing and settlement of securities. In addition to covering these issues, this section also discusses future challenges and options for policy and market design.

\section{I MARKET FAILURES AND BARRIERS TO INTEGRATION}

It is often argued that the payment and settlement system industry is characterised by market failures and that there is a public good element inherent in such systems. Indeed, payment and settlement systems typically exhibit positive externalities because not only the participants but also the economy as a whole benefit from the smooth functioning of payment and settlement systems. From that perspective, it is evident that the public has an interest in sound payment and settlement systems. Whether that would justify some form of public intervention, however, is difficult to say. How difficult it is to define the role of the public in network economies can also be illustrated by recent experiences in the utility industries such as telecommunications, electricity, transportation, water supply, etc.

Regardless of the question of whether central banks should operate their own systems, there is a role for central banks to foster the process of integration in the clearing and settlement

28 See also ECB (2004) for further background information on securities settlement systems and financial stability. 
industry. On the one hand, there is clear theoretical and empirical evidence that, in many markets, market-driven solutions are generally best at allocating resources efficiently. Therefore, market forces can be expected to lead to an efficient securities infrastructure. On the other hand, markets may fail if constraints on market forces prevent their coming into force. In particular, market power and the lack of competition may hamper further consolidation. Moreover, it is unclear what the final and optimal market outcome should be. On the one hand, a single infrastructure is likely to maximise network externalities and economies of scale. On the other hand, these advantages have to be balanced against the inefficiencies that may be caused by the absence of competition.

The Giovannini Group - meeting under the chairmanship of Alberto Giovannini - is composed of experts from the private sector who advise the European Commission on issues regarding the financial sector. The Group began working on EU clearing and settlement arrangements early in 2001 under a mandate from Commissioners Solbes and Bolkestein. The Commission's interest in this field relates to its responsibilities in creating an internal market in financial services and in ensuring that the euro is underpinned by an efficiently functioning financial system. The mandate given to the Group had three main elements: (i) to identify the sources of inefficiency in cross-border (or cross-system) clearing and settlement activities and to consider how to remove them; (ii) to identify the public policy considerations in ensuring a more efficient, i.e. a more integrated, EU clearing and settlement environment; and (iii) to assess various models of integration in terms of these public policy considerations.

In approaching the mandate from the Commission, the Group adopted the classic approach of diagnosing the problems in EU clearing and settlement arrangements before recommending any solutions. It produced two reports. The first report on EU clearing and settlement arrangements, published in November 2001, was diagnostic. The objective of the report was to introduce clearing and settlement to the uninitiated reader, to highlight the specific problems of cross-border clearing and settlement and to identify the source of these problems. The Group identified the source of the problems as being 15 barriers stemming from market practices and regulatory requirements, tax procedures and issues of legal certainty.

The second report, from April 2003, attempted to provide a coherent strategy for removing the 15 barriers identified in the 2001 report. To this end, precise actions were identified for removing the barriers and clear responsibilities were attributed for carrying out these actions. In particular, these actions included the removal of barriers related to the harmonisation of operating hours and settlement deadlines, the guarantee of intraday settlement finality in all links between settlement systems and the removal of practical impediments to remote access to national clearing and settlement systems. The Group agreed that the integration process should be led by the market, but the fundamental importance of clearing and settlement as regards the functioning of securities markets imposes a special role on the public authorities in promoting the integration process. For example, the removal of some barriers may require legislative action. The ECB has also been asked to contribute to the removal of some barriers, together with other central banks within the framework of the ESCB and with securities regulators within the ESCBCESR Working Group.

The work of the Giovannini Group has identified a number of barriers to efficient cross-border clearing and settlement in the EU. These barriers tend to reduce or eliminate competition, thereby allowing market power to emerge. While it is clear that the elimination of these barriers is a necessary condition for an efficient infrastructure to emerge, it is less 
clear whether it is also a sufficient condition. In theory, once the barriers have been removed, market forces can develop freely and an efficient market infrastructure could emerge unless there are some forms of market failure.

The complexity of the different interests at stake has an impact on the competitive environment of the securities service industry. The markets have difficulties in allocating the overall benefits that can be reaped from the shift to a consolidated infrastructure. Those who would bear the costs of integration are not necessarily the same players who would derive most of the benefits from it. As the net benefits of consolidation are not shared evenly, users and providers of clearing and settlement services can have different strategic interests. Differences in strategic interest arise not only between the various institutions involved in clearing and settlement, but even within individual institutions because of the multiple roles that a single entity can play. Some institutions (e.g. custodian banks) may benefit from fragmentation. Since they are in many cases also the owners of the settlement system, they may have both an interest in fragmentation continuing and the power to make sure it does. In addition, there is a timing difference which produces conflicts between short-term and long-term gains. Finally, the existence of what is sometimes referred to as "silos", i.e. vertically integrated structures, further adds to the problem. For example, an exchange that owns a settlement system can "encourage" its users to settle in the settlement system it owns.

There are various forms of integration in the securities clearing and settlement infrastructure, such as interoperability, alliances, joint ventures and mergers. All of these approaches can help to improve market efficiency. Market participants need to look for solutions which are optimal in the long run, i.e. capable of maximising economies of scale and minimising the average transaction costs to the final users. However, it is acknowledged that, in practice, interim solutions could be necessary.
The three main driving forces pushing market participants to adopt efficient solutions in the field of market infrastructure are competitive pressures, cooperation between market participants and, when needed, policy decisions. The process of consolidation should in general be driven by the private sector, which, however, does not mean that there are no public policy issues involved. Public authorities should help by removing unfair and unjustified barriers to integration and competition, such as legal impediments and a lack of standardisation.

\subsection{PUBLIC AND PRIVATE SECTOR INITIATIVES}

Efficient cross-border clearing and settlement processes are essential to allow market participants to operate effectively in an integrated EU financial market. Given the heterogeneous nature of the obstacles and the challenges, the integration of the infrastructure requires a differentiated and pragmatic approach which encompasses a large variety of legislative and non-legislative instruments. Taking this notion into account, both authorities and market participants have jointly acknowledged that further integration of European securities clearing and settlement systems requires coordinated action by private and public sector bodies. Recently, numerous efforts, projects, and actions have been initiated to address and overcome the highly complex and fragmented cross-border clearing and settlement structures in the EU. This section reviews various current public and private initiatives to tackle the issues outlined above.

Industry associations, for example the Federation of European Stock Exchanges (FESE), the European Association of Central Counterparty Clearing Houses (EACH) and the European Central Securities Depository Association (ECSDA), have launched initiatives aimed at achieving greater integration and furthering harmonisation. For example, the ECSDA has created a working 
group supporting the Giovannini Group's work aimed at removing barriers. However, national interests often hinder their success. Finally, the European Monitoring Group of the G30 has recently been established, in which the ECB will also be represented. This Group will support the Giovannini Group's work aimed at removing barriers to integration.

The Group of Thirty is a private sector initiative that brings together representatives of both private and public sector authorities and is designed to complement the CPSS/ IOSCO recommendations for major, global securities settlement infrastructures. For this purpose, it has recently adopted an action plan for the development of the securities settlement infrastructure in developed jurisdictions over a period of five years.

From a legal perspective, two EU Directives have made a significant step towards further integration in the field of securities posttrading business and arrangements. In May 1998 the European Commission adopted a Settlement Finality Directive, which aimed to reduce the systemic risk associated with participation in payment and securities settlement systems and, in particular, the risk linked to the insolvency of a participant in such a system. The Directive applies to payment and securities settlement systems, participants in such systems, collateral security provided in connection with participation in a system, or operations of the national central banks of the Member States in their functions as central banks.

In addition, the European Commission adopted a Directive for the use of collateral, which the EU Member States were to implement by 27 December 2003. The harmonised collateral rules are supposed to lower credit losses and encourage cross-border business and competitiveness. Moreover, the creation of a uniform EU legal framework is intended to contribute to greater integration and costefficiency of European financial markets.
On 28 April 2004 the European Commission released a "Communication on clearing and settlement". The Communication includes an action plan outlining the various initiatives necessary to achieve an integrated, safe and efficient clearing and settlement environment for securities trading in the EU, based on a level playing field for the different providers of services. More specifically, the Commission set up a Clearing and Settlement Advisory and Monitoring Expert group (the CESAME group), which assists the Commission in removing existing barriers to integration in clearing and settlement, in particular to improve the cross-border post-trading environment. The group is composed of around 20 high level representatives of various, mainly private bodies involved in clearing and settlement, along with four observers from public authorities, including the ECB. Moreover, the Commission has proposed a framework for a Directive on Clearing and Settlement by late $2005 .{ }^{29}$

\subsection{THE ECB'S ROLE AND INITIATIVES}

The final outcome of the current process of reshaping the securities industry will be the result not only of competition and market forces, but also of cooperation between market participants and public authorities and, eventually, of policy decisions. As the integration process in the area of settlement systems touches upon the key responsibilities of the Eurosystem (i.e. the sound execution of monetary policy, the smooth functioning of payment systems, and the preservation of financial stability), the ECB/Eurosystem has played an active role in fostering integration in the following ways:

\section{REMOVING OBSTACLES TO INTEGRATION AND ACTING AS A CATALYST}

The ECB has made a concerted effort to help remove obstacles to integration. For example, the ECB will help to remove some of the

29 For further details, see http://europa.eu.int/comm/ internal_market/financial-markets/clearing/index_en.htm. 
barriers identified by the Giovannini Group in the context of the ESCB-CESR, which will facilitate competition between different clearing and settlement systems across the EU. In particular, these include the removal of barriers related to the harmonisation of operating hours and settlement deadlines, the guarantee of intraday settlement finality in all links between settlement systems, and the removal of practical impediments to remote access to national clearing and settlement systems. Owing to the network effects and scale economies inherent in clearing and settlement, competition can be expected to foster integration without favouring any particular model of integration, but leaving the integration process in the hands of the private sector. In addition, the Eurosystem's contribution in this regard has focused on acting as a catalyst for improvement by encouraging discussions among the relevant players. The ECB has established the Contact Group on Euro Securities Issues (COGESI) for this purpose.

\section{SETTING STANDARDS}

The establishment of public standards for clearing and settlement systems is essential not only in order to prevent systemic risks that could potentially threaten the stability of the financial system, but also in order to spur integration. Against this background, the Eurosystem, in cooperation with the Committee of European Securities Regulators (CESR), has developed standards for $\mathrm{EU}$ clearing and settlement systems. These standards will help to increase further the level of integration. The Eurosystem has also contributed to the work of a joint central bank and securities regulators task force at the level of the G10, aimed at developing recommendations for central counterparty clearing houses. Most likely, these recommendations for CCPs will be transformed into European standards at a later stage and will help to foster integration in the field of central counterparty clearing.

\section{ENSURING AN INTEGRATED REGULATORY AND OVERSIGHT FRAMEWORIK}

Cooperation between all the relevant authorities is essential in order to establish effective risk management standards for clearing and settlement systems and to avoid regulatory arbitrage. A regulatory level playing field is a key requirement for ensuring integration. There have been numerous occasions where securities regulators, central banks and banking supervisors have initiated joint work. For example, the Eurosystem takes the view that the current transformation of the CPSS-IOSCO Recommendations into European standards by the ESCB-CESR Working Group has been a major achievement in the direction of an integrated regulatory framework for clearing and settlement in Europe.

\section{EU ENLARGEMENT}

In view of the EU accession process and the future participation of the new EU Member States in the euro area, a large number of reforms have taken and are taking place in the countries concerned. It has been and will continue to be one of the priorities of the Eurosystem and the ECB in particular to assist the new EU Member States in developing safe and efficient financial securities clearing and settlement infrastructures. For example, technical assistance has been offered in the implementation of procedures allowing the introduction of delivery versus payment (DVP) mechanisms and the effective management of collateral. The aim of these initiatives is twofold: first, to ensure that the domestic infrastructures are sufficiently safe and robust to avoid systemic risks and possible contagion problems across the EU in the event of major events; and second, to stimulate the integration of infrastructures and procedures and to bring them into line with EU requirements, thereby ensuring the smooth functioning of their settlement systems in an EU environment. 


\section{FACILITATING AND HARMONISING CENTRAL BANK PROCEDURES}

The Eurosystem has made efforts to further harmonise central bank procedures and operations. For example, the Eurosystem has implemented the so-called correspondent central banking model (CCBM) to ensure that all assets eligible for use either in monetary policy operations or to obtain liquidity in TARGET are available to all its counterparties, regardless of where the assets or the counterparty are situated. Counterparties to the monetary policy operations of the Eurosystem and participants in TARGET can only obtain credit from the national central bank of the country in which they are based. As the NCBs normally only have accounts with the local settlement system, the counterparties would typically only use collateral deposited in that local settlement system. The CCBM enables counterparties also to use collateral deposited in settlement systems in other countries. To do

\section{Table 8 Committees and initiatives in the field of securities clearing and settlement regulation, supervision and integration}

\begin{tabular}{|c|c|c|}
\hline Committee & Objective & ECB involvement \\
\hline $\begin{array}{l}\text { Contact Group on Euro } \\
\text { Securities Issues (COGESI) }\end{array}$ & $\begin{array}{l}\text { Forum for the central banks and representatives from the banking } \\
\text { and securities settlement industries of the euro area and of the } \\
\text { Eurosystem to discuss issues and developments that are relevant } \\
\text { for the euro securities settlement industry. }\end{array}$ & Chair and Secretariat \\
\hline $\begin{array}{l}\text { Committee on Payment and } \\
\text { Settlement Systems (CPSS) }\end{array}$ & $\begin{array}{l}\text { Forum for the central banks of the Group of Ten countries (G10) } \\
\text { to monitor and analyse developments in domestic payment, } \\
\text { settlement and clearing systems, as well as in cross-border and } \\
\text { multicurrency settlement schemes. }\end{array}$ & Member \\
\hline $\begin{array}{l}\text { CPSS - Working Group on } \\
\text { Cross-Border Collateral }\end{array}$ & $\begin{array}{l}\text { Identification and evaluation of existing institutional arrangements } \\
\text { under which central banks accept foreign collateral on either a } \\
\text { routine or emergency basis to support intraday or overnight credit, } \\
\text { and evaluation of alternative models for the acceptance of foreign } \\
\text { collateral in a conceptual way. }\end{array}$ & Member and Chair \\
\hline $\begin{array}{l}\text { CPSS - Working Group on } \\
\text { Oversight of Payment and } \\
\text { Settlement Systems }\end{array}$ & $\begin{array}{l}\text { Mapping and comparison of central banks' objectives, } \\
\text { methodologies and tools for as well as common features in their } \\
\text { oversight policies and activities. }\end{array}$ & Member \\
\hline $\begin{array}{l}\text { Clearing and Settlement } \\
\text { Advisory and Monitoring } \\
\text { Expert Group (CESAME) }\end{array}$ & $\begin{array}{l}\text { To assist the Commission with Level } 1 \text { legislation, the } \\
\text { implementation of the Directive on Clearing and Settlement }\end{array}$ & Observer \\
\hline $\begin{array}{l}\text { ESCB and Committee of } \\
\text { European Securities Regulators } \\
\text { Working Group (ESCB-CESR) }\end{array}$ & $\begin{array}{l}\text { Creation of a level playing field for different categories of service } \\
\text { providers; development of a common set of standards that meet the } \\
\text { needs of both regulators and central bankers; promotion of further } \\
\text { harmonisation and integration in the EU. }\end{array}$ & Member and Co-Chair \\
\hline $\begin{array}{l}\text { Ad-hoc joint ESCB Market } \\
\text { Operations Committee and } \\
\text { Payment and Securities Settlement } \\
\text { Committee (MOC-PSSC) }\end{array}$ & $\begin{array}{l}\text { Assistance in the review of the Eurosystem's collateral framework, } \\
\text { e.g. introduction of the Single List of eligible assets, based on euro } \\
\text { area eligibility criteria. }\end{array}$ & Member and Secretariat \\
\hline $\begin{array}{l}\text { ESCB Payment and Securities } \\
\text { Settlement Committee (PSSC) }\end{array}$ & $\begin{array}{l}\text { Assistance in the fulfilment of the ESCB's statutory duty to } \\
\text { promote the smooth operation of payment systems, including } \\
\text { business continuity aspects, in particular by advising on: (i) the } \\
\text { operation and maintenance of TARGET and of the correspondent } \\
\text { central banking model (CCBM) for the cross-border use of } \\
\text { collateral; (ii) general payments systems policy and oversight } \\
\text { issues; and (iii) issues of interest to central banks in the field of } \\
\text { securities clearing and settlement systems. }\end{array}$ & Member and Secretariat \\
\hline
\end{tabular}

Source: ECB 
so, the counterparties must arrange with the foreign settlement system for the collateral to be transferred to an account maintained by the NCB in that country. This NCB will then hold the collateral on behalf of the NCB granting the credit. It should be noted that the CCBM is supposed to be a medium-term solution. It is designed to facilitate the cross-border use of collateral until adequate market solutions become available throughout the euro area.

As explained above, the ECB/Eurosystem has been active in a number of areas aimed at fostering integration. Table 8 summarises the involvement of the ECB in the various committees and initiatives in the field of securities clearing and settlement regulation, supervision, stability and integration.

\subsection{FUTURE CHALLENGES AND OPTIONS FOR POLICY AND MARKET DESIGN}

A common domestic infrastructure for the euro is crucial for achieving integrated markets. As described earlier, substantial barriers continue to exist in this area, resulting in a highly fragmented European securities infrastructure, in particular with regard to efficient crossborder clearing and settlement. Against this background, a number of open issues have emerged at the forefront of policy debates with regard to future challenges and options for further integration of the securities services infrastructure in Europe.

\section{CORPORATE GOVERNANCE STRUCTURE}

The first issue relates to the question of whether there is a need for agreed best practices as regards governance. As seen in Section 1.3, the ongoing reorganisation and integration has, so far, been in the form of legal mergers. As a result, trading, clearing and settlement infrastructure providers have become integral parts of complex financial groups, either in the form of vertical or horizontal companies. Different conflicts of interest might exist in each of the two models if the management of the parent institution pursues its overall interests and goals at the expense of other affiliates or business areas (Russo et al., 2004). Conflicts of interest that might arise in the operation of a vertically integrated silo relate to the privileged distribution of profits or investments across different business areas within the financial group, a policy of price bundling and potential cross-subsidisation of one or more services, the "rigidity" of IT infrastructure investments impairing the efficiency of the securities settlement system, and possibly biased decision-making in the event that the default of the entire group would favour particular interest groups, such as owners, exchange members or domestic members. However, similar or additional conflicts of interest might exist in horizontal groups. Given that consolidation of the securities trading, clearing and settlement industry is quite a recent phenomenon, actual or potential conflicts of interest in financial groups might give rise to possible adequate and best corporate governance practices and mechanisms being developed and introduced in the entire group structure.Current consolidation initiatives in the securities infrastructure industry coupled with the increase of cross-border trading have also had a significant effect on the adequate and equal representation of the interests of non-domestic customers and system participants vis-à-vis their domestic counterparts. In this respect, appropriate governance mechanisms should be used to make sure that the stakes and interests of those non-domestic participants and customers are adequately and fairly reflected in the decision-making processes and advisory groups (Russo et al., 2004).

As outlined in Russo et al. (2004), it cannot be ruled out that the heterogeneity and possible inadequacies in current governance arrangements of European securities clearing and settlement systems are impeding the process of further consolidation and integration. In this respect, European-wide efforts in cooperation with national authorities might be appropriate in order to consider the development of harmonised structures which would preserve public interest in and create 
equal conditions of competition for the providers of securities infrastructures. In this way, optimal conditions could be achieved in this field, thereby enabling maximum benefit to be reaped from the completion of the internal market relating to securities settlement systems.

\section{DIVERSIFICATION OF ACTIVITIES}

In the process of integrating into an increasing number of financial groups, securities settlement systems might try to expand their activities into new areas of business. These new services and products, such as credit and collateral management services, would supplement or go beyond their traditional core lines of business. A monopolistic or quasimonopolistic position in their core business might enable (I)CSDs to bundle or make the provision of their banking services conditional on the use of its settlement services. ${ }^{30}$ This has the potential to result in anti-competitive links between the different services provided by the financial group and to challenge the position of its competitors, for example banks or global custodians. In turn, banks or custodians might not be able to branch into the market of the ICSDs with equivalent conditions as they are subject to different regulations and have a different legal status. Currently, trading, clearing, custody and settlement service providers compete within the existing local and regulatory framework. Some issues of anticompetitive behaviour might be successfully addressed and prevented. However, in the face of increased consolidation across borders, it is unclear whether the variations and disparities among the current national regulations in the Member States necessarily guarantee public interests in equivalent and fair market conditions to the greatest extent possible. For these reasons, consistent and harmonised regulation and oversight of securities clearing and settlement infrastructure and service providers should be encouraged.

\section{RISK MANAGEMENT}

In consolidated company structures, potential conflicts related to risk management might emerge and would need to be carefully addressed. For example, a CCP pools risks and must manage those risks when it interposes itself between the buyer and the seller of a financial transaction. This is particularly relevant for vertically integrated groups, i.e. when the CCP is part of a division of an exchange and is not a stand-alone legal entity. In this case, it is important that risk management arrangements are well designed and decisions are not distorted by the commercial objectives of the other business activities of the CCP. Therefore, the effectiveness of the risk control of a CCP and the adequacy of its financial resources are critical aspects of the infrastructure of the markets it serves. In this light, the CPSS/ IOSCO concluded that international standards for CCP risk management are a critical element in promoting the safety and stability of financial markets.

\section{CONSOLIDATION AND COMPETITION}

Another important issue relates to the question of whether the consolidation process respects competition rules. As mentioned earlier, integration might tend to reduce, on average, the number of different systems that are involved or to harmonise procedures, thereby ensuring and increasing inter-linkages and the interoperability of various systems. Consequently, consolidation of the securities market infrastructure has the potential to concentrate activities within a few large systems. In such circumstances, securities clearing and settlement system operators may attempt to adopt and engage in business practices that constitute an unreasonable abuse of market dominance at the expense of customers and other competitors. Subsidisation and price bundling by linking one service to the use of other services are prominent examples of unfair practices if they are not undertaken for legitimate reasons. In addition, the dominant or monopolistic CSD or

30 As mentioned in Section 3.1, aspects related to the expansion of SSSs' core activities have been further elaborated in the theoretical papers by Holthausen and Tapking (2004) and Rochet (2004). 
CCP will tend to be less willing to invest in innovations and new technologies in a market with relatively high barriers to entry than in a competitive environment, because its dominant position is less likely to be challenged. These business practices impede the crystallisation of optimal clearing and settlement arrangements to the detriment of the proper functioning of the overall capital market and economy. To address these deficiencies, public authorities have a keen interest in ensuring and maintaining a competitive market environment. Therefore, it is essential that the policy objectives of public authorities are guided by the principles of fair pricing, fair and objective access and exit criteria, and cost efficiency, thereby creating a market environment with adequate service levels for customers and participants.

\section{REGULATION AND SUPERVISION}

A further important aspect arising from the consolidation and integration of European infrastructures is the debate on the future shape of the regulation and supervision of multinational providers of infrastructure at the European level over the medium to long term. International infrastructures are more likely than their national counterparts to create market conditions in which potential disturbances and disruptions could generate severe contagion and systemic failures. For example, excessive risks inherent in international financial infrastructure groups can stem from the fact that intermediaries and providers are heavily engaged in cross-border activities. Given a relatively longer transaction value and processing chain for cross-border transactions, the expansion of international activities might entail problems relating to the lack of legal harmonisation for access to systems, or to technical problems resulting from insufficient standardisation and incompatible communication protocols and interfaces. This gives rise to a higher degree of systemic risks and a higher default rate for cross-border activities. Against this background, regulation and supervision of international market infrastructure providers has become of key importance in ensuring and preserving financial stability.Oversight in the field of clearing and settlement is not yet regulated at the European level. In the light of the multiplicity of relevant authorities such as regulators, supervisors and overseers in the various Member States, there is a need for a coherent and effective regulatory/supervisory/ oversight framework, which would involve all the relevant authorities acting together.

So far, rules for cooperation between relevant authorities have mostly been established via bilateral memoranda of understanding. However, the ongoing structural changes and parallel developments in payment systems require a closer focus on the coordination of supervision and oversight. Current arrangements for banking regulation and supervision are based on the "home country" principle. According to the "home country control" model, the relevant home authority is the lead overseer of the consolidated entity for international financial groups. In the field of clearing and settlement, however, the applicability of the traditional division of tasks between home and host authorities will be less evident following further integration and consolidation. It is also not immediately obvious whether a model based on the "home country control" principle is appropriate to address and mitigate potential risks for the main multinational infrastructure providers. Moreover, in each institutional case the needs may differ, as the importance of a system may vary from country to country. Specific roles may also vary.

The systemic and cross-border characteristics of the clearing and settlement infrastructure imply that there will be authorities that have the responsibility for the supervision/oversight of securities clearing and settlement systems, both at the national level and in the crossborder context. Moreover, strong cooperation between all the competent authorities is necessary to fulfil these responsibilities. To achieve this, one feasible option might include coordinating functions being entrusted to one 
of those authorities. In conclusion, the issue of whether or not the oversight/regulatory/ supervisory framework should be based on the home country principle and a coordinating authority depends on a range of different factors and needs to be adjusted to each specific case. In any event, in order to properly address all the associated challenges, the development of a harmonised regime would require a high level of cooperation and consultation among the EU institutions, the competent national authorities and the industry as a whole.

It should be noted that many of these challenges are being addressed in the context of the work of ESCB-CESR. Some considerable progress towards finding adequate solutions can thus be expected in the future.

\section{CONCLUSION}

This paper has examined the state and process of integration of the securities market infrastructures in the euro area. The key intention has been to ascertain the extent to which market infrastructures have been integrated. The integration of financial infrastructures builds upon one of the key responsibilities of the Eurosystem, since it facilitates its policy goals with respect to a smooth execution of monetary policy, the sound and efficient functioning of payment systems, and the preservation and promotion of financial stability.

We have defined the integration of the securities market infrastructure as a situation where, on a European-wide scale, all assets of a particular type are handled according to a single infrastructure, where users face identical access conditions to the respective trading, clearing and settlement systems, and where participants are treated equally both within and across systems.

There have been significant changes in market infrastructures in the euro area in recent years and these have pointed towards increased integration and consolidation among market infrastructure providers. In the European context, these changes have been driven by the introduction of the euro, technological advances and increased cross-border transactions, coupled with growing demand for less costly and complex international securities trading, clearing and settlement structures. However, despite the single currency, the euro area securities infrastructure remains highly fragmented and insufficiently integrated. There is still a high number of providers for trading, clearing and settlement and they are not efficiently connected to each other. Moreover, we find that the degree of consolidation varies between different integrated groups or segments of market infrastructure. While less integrated structures prevail in the field of trading and securities settlements systems, the process of system integration has been relatively more pronounced in the field of central counterparty clearing. As a result of strong economies of scale and scope and positive network externalities inherent in the securities trading, clearing and settlement business, it can be concluded that substantial cost savings and increased technical efficiency can be expected from further integration along the transaction processing chain. This prospect has already encouraged providers to move towards integration, but the process is still in its infancy.

Despite its importance for the prosperity, efficiency and stability of capital markets, it is only recently that a few academic studies have focused attention on the institutional set-up and the organisation of securities market infrastructures. The empirical literature and cost studies in this area confirm that the current arrangements in the European securities market infrastructure are less than optimal, therefore suggesting that there is a relatively high potential for cost saving especially as far as cross-border clearing and settlement in Europe are concerned. Economies of conglomeration and critical mass are likely to favour centralisation and consolidation of 
European trading, clearing and settlement systems. Theoretical papers have proposed and analysed some complementary solutions for possible future market infrastructure design. Given the limited number of theoretical contributions at this stage, it would appear to be premature to draw any final conclusions regarding policy and the optimal form of consolidation. Further research and careful analysis in this area are clearly warranted and encouraged.

The most relevant factors underlying the less than advanced state of the integration of financial market infrastructures are likely to be not only persistent cross-border differences in tax regimes, procedures and laws, but also vested interests among users, owners and management of the systems. As identified by the Giovannini Group, these barriers tend to discourage or eliminate competition among system operators and prevent the necessary conditions for an efficient securities infrastructure to emerge.

Given the heterogeneous nature of the obstacles to integration, public authorities and market participants have launched a number of initiatives in order to keep pace with the changes in the market and the challenges to fostering integration. In particular, the Eurosystem has played an active role in this process and has made significant contributions to the definition of harmonised standards and cooperative arrangements aimed at promoting further integration of new cross-border infrastructures. The joint work of the CESR and the ESCB can certainly be seen as a decisive step towards the harmonisation of market practices and standards and it will be a catalyst for the integration of securities market infrastructures in the euro area. It may also promote the integration and development of safe and efficient financial securities clearing and settlement infrastructures in the new EU Member States.

Regarding the future shape of the European securities market infrastructure, continued and increased consolidation and integration among the participants involved in the transaction processing chain is likely to take place in the near future. However, the success of further consolidation and integration will depend on a number of fundamental issues which are still to be addressed. These include potential conflicts of interest arising from inappropriately designed governance mechanisms, issues relating to central counterparty clearing and competition, and the development of a coherent and effective oversight and supervisory framework. The work of the ESCB-CESR can be expected to be helpful in addressing these challenges. 



\section{REFERENCES}

Adam, K., Jappelli, T., Menichini, A. M., Padula, M. and M. Pagano (2002), “Analyse, compare, and apply alternative indicators and monitoring methodologies to measure the evolution of capital market integration in the European Union", Report to the European Commission.

Adjaouté, K. and J.-P. Danthine (2003), "European financial integration and equity returns: A theory-based assessment", in Gaspar, V. et al., "The transformation of the European financial system", ECB, Frankfurt/Main.

Ayuso, J. and R. Blanco (1999), "Has financial market integration increased during the 1990s?", Documentos de trabajo/Banco de España, pp. 9923-9958.

Baele, L., Ferrando, A., Höhrdahl, P., Krylova, E. and C. Monnet (2004), "Measuring financial integration in the euro area", ECB Occasional Paper Series, No 14, April 2004.

Cabral, I., Dierick, F. and J. Vesala (2002), "Banking integration in the euro area", ECB Occasional Paper Series, No 6, December 2002.

Cybo-Ottone, A., Di Noia, C. and M. Murgia (2000), "Recent developments in the structure of securities markets", Brookings-Wharton Papers on Financial Services.

Deutsche Börse Group (2005), “The European Post-Trade Market: An Introduction”, Deutsche Börse Group White Paper.

Domowitz, I. (1995), "Electronic derivatives exchanges: implicit mergers, network externalities and standardization", The Quarterly Review of Economics and Finance, 35 (2), pp. 163-175.

Domowitz, I. and B. Steil (1999), "Automation, trading costs, and the structure of the trading services industry", Brookings-Wharton Papers on Financial Services.

Economides, N. (1993), "Network economics with application to finance", Financial Markets, Institutions \& Instruments, 2 (5), pp. 89-97.

Economides, N. and A. Siow (1988), "The division of markets is limited by the extent of liquidity (spatial competition with externalities)", The American Economic Review, 78 (1), pp. 108-121.

European Central Bank (2004), “Financial stability review”, December 2004.

European Central Bank (2003), "The integration of Europe's financial markets", article in the October 2003 issue of the ECB's Monthly Bulletin.

European Central Bank (2000), "Consolidation in the securities settlement industry", article in the February 2000 issue of the ECB's Monthly Bulletin.

Gaspar, V., Hartmann, P. and O. Sleijpen (eds.) (2003), "The transformation of the European financial system", ECB, Frankfurt/Main. 
Giddy, I., Saunders, A. and I. Walter (1996), "Alternative models for clearance and settlement: the case of the single European capital market", Journal of Money, Credit, and Banking, 28 (4), pp. 986-1000.

Giovannini Group (2001), "Cross-border clearing and settlement arrangements in the European Union”, Discussion paper, European Commission.

Giovannini Group (2003), "Second report on EU clearing and settlement arrangements", Discussion paper, European Commission.

Hartmann, P., Maddaloni, A. and S. Manganelli (2003), "The euro area financial system: structure, integration and policy initiatives", Oxford Review of Economic Policy, 19 (1), pp. 180-213.

Hasan, I., Malmakäki, M. and H. Schmiedel (2003), "Technology, automation, and productivity of stock exchanges: international evidence", Journal of Banking and Finance, 27, pp. 1743-1773.

Hasan, I. and H. Schmiedel (2004), "Networks and equity market integration: European evidence", International Review of Financial Analysis, 13, pp. 601-619.

Holthausen, C. and J. Tapking (2004), "Raising rival's costs in the securities settlement industry”, ECB Working Paper Series, July 2004.

Kauko, K. (2004), "Links between securities settlement systems: an oligopoly theory approach", International Review of Financial Analysis, 13, pp. 585600.

Kauko, K. (2003), “Interlinking securities settlement systems: a strategic commitment?”, Bank of Finland Discussion Papers, 26/2003.

Knieps, G. (2004), "Competition in the post-trade markets: a network economic analysis of the securities business", University of Freiburg, Institut für Verkehrswissenschaft und Regionalpolitik, Discussion Paper Series, 101/2004.

Koeppl, T. and C. Monnet (2004), "Guess what: it's the settlements!", ECB Working Paper Series, July 2004.

Lee, R. (1998), "What is an exchange? The automation management and regulation of financial markets", Oxford University Press Inc., New York.

Leinonen, H. (2003), "Restructuring securities systems processing - a blue print proposal for real-time/t+0 processing", Bank of Finland Discussion Papers, 7/2003.

London Economics (2002), "Quantification of the macro-economic impact of integration of EU financial markets", Final report to the European Commission, November 2002.

Malkamäki, M. and J. Topi (1999), "Strategic Challenges for Exchanges and Securities Settlement", Bank of Finland Discussion Papers, 21/1999. 
Milne, A. (2002), "Competition and the rationalisation of European securities clearing and settlement”, Working Paper, City University Business School, London.

Rochet, J.-C. (2004), "The welfare effects of vertical integration in the securities clearing and settlement industry”, IDEI, Toulouse University, unpublished manuscript.

Russo, D., Hart, T., Malaguti, M. C. and C. Papathanassiou (2004), "Governance of securities clearing and settlement systems”, ECB Occasional Paper Series, No 21, October 2004.

Schmiedel, H. (2003), "Technological development and concentration of stock exchanges in Europe", Research Banking and Finance, 3, pp. 381-408.

Schmiedel, H., Malkamäki, M. and J. Tarkka (2002), "Economies of scale and technological development in securities depository and settlement systems", Bank of Finland Discussion Papers, 26/2002.

Serifsoy, B. and M. Weiss (2003), "Efficient systems for the securities transaction industry A framework for the European Union”, Johann Wolfgang Goethe-University, Frankfurt/Main, Working Paper Series: Finance and Accounting, 120/2003.

Shy, O. (2001), "The economics of network industries", Cambridge University Press, New York.

Stockmann, A. C. (1988), "On the roles of international financial markets and their relevance for economic policy", Journal of Money, Credit and Banking, 20 (3), pp. 531-549.

Tapking, J. and J. Yang (2004), "Horizontal and vertical integration in securities trading and settlement”, ECB Working Paper Series, 387/2004, August 2004.

Van Cayseele, P. (2004), "Competition and the organisation of the clearing and settlement industry”, C.E.S., K.U.Leuven Discussion Paper.

Van Cayseele, P. and C. Wuyts (2005), "Cost Efficiency in the European Securities Settlement and Safekeeping Industry”, K.U.Leuven, Belgium, Discussion Paper. 


\section{EUROPEAN CENTRAL BANK}

OCCASIONAL PAPER SERIES

1 "The impact of the euro on money and bond markets" by J. Santillán, M. Bayle and C. Thygesen, July 2000.

2 "The effective exchange rates of the euro" by L. Buldorini, S. Makrydakis and C. Thimann, February 2002.

3 "Estimating the trend of M3 income velocity underlying the reference value for monetary growth" by C. Brand, D. Gerdesmeier and B. Roffia, May 2002.

4 "Labour force developments in the euro area since the $1980 \mathrm{~s}$ " by V. Genre and R. Gómez-Salvador, July 2002.

5 "The evolution of clearing and central counterparty services for exchange-traded derivatives in the United States and Europe: a comparison" by D. Russo, T. L. Hart and A. Schönenberger, September 2002.

6 "Banking integration in the euro area" by I. Cabral, F. Dierick and J. Vesala, December 2002.

7 "Economic relations with regions neighbouring the euro area in the "Euro Time Zone" by F. Mazzaferro, A. Mehl, M. Sturm, C. Thimann and A. Winkler, December 2002.

8 "An introduction to the ECB's survey of professional forecasters" by J. A. Garcia, September 2003.

9 "Fiscal adjustment in 1991-2002: stylised facts and policy implications" by M. G. Briotti, February 2004.

10 "The acceding countries' strategies towards ERM II and the adoption of the euro: an analytical review" by a staff team led by P. Backé and C. Thimann and including O. Arratibel, O. Calvo-Gonzalez, A. Mehl and C. Nerlich, February 2004.

11 "Official dollarisation/euroisation: motives, features and policy implications of current cases" by A. Winkler, F. Mazzaferro, C. Nerlich and C. Thimann, February 2004.

12 "Understanding the impact of the external dimension on the euro area: trade, capital flows and other international macroeconomic linkages" by R. Anderton, F. di Mauro and F. Moneta, March 2004

13 "Fair value accounting and financial stability" by a staff team led by A. Enria and including L. Cappiello, F. Dierick, S. Grittini, A. Maddaloni, P. Molitor, F. Pires and P. Poloni, April 2004.

14 "Measuring Financial Integration in the Euro Area" by L. Baele, A. Ferrando, P. Hördahl, E. Krylova, C. Monnet, April 2004. 
15 "Quality adjustment of European price statistics and the role for hedonics" by H. Ahnert and G. Kenny, May 2004.

16 "Market dynamics associated with credit ratings: a literature review" by F. Gonzalez, F. Haas, R. Johannes, M. Persson, L. Toledo, R. Violi, M. Wieland and C. Zins, June 2004.

17 “Corporate ‘Excesses' and financial market dynamics” by A. Maddaloni and D. Pain, July 2004.

18 "The international role of the euro: evidence from bonds issued by non-euro area residents" by A. Geis, A. Mehl and S. Wredenborg, July 2004.

19 "Sectoral specialisation in the EU a macroeconomic perspective" by MPC task force of the ESCB, July 2004.

20 "The supervision of mixed financial services groups in Europe" by F. Dierick, August 2004.

21 "Governance of securities clearing and settlement systems" by D. Russo, T. Hart, M. C. Malaguti and C. Papathanassiou, October 2004.

22 "Assessing potential output growth in the euro area: a growth accounting perspective" by A. Musso and T. Westermann, January 2005.

23 "The bank lending survey for the euro area" by J. Berg, A. van Rixtel, A. Ferrando, G. de Bondt and S. Scopel, February 2005.

24 "Wage diversity in the euro area: an overview of labour cost differentials across industries" by V. Genre, D. Momferatou and G. Mourre, February 2005.

25 "Government debt management in the euro area: recent theoretical developments and changes in practices" by G. Wolswijk and J. de Haan, March 2005.

26 "The analysis of banking sector health using macro-prudential indicators" by L. Mörttinen, P. Poloni, P. Sandars and J. Vesala, March 2005.

27 "The EU budget - how much scope for institutional reform?" by H. Enderlein, J. Lindner, O. Calvo-Gonzalez, R. Ritter, April 2005.

28 "Reforms in selected EU network industries" by R. Martin, M. Roma, I. Vansteenkiste, April 2005.

29 "Wealth and asset price effects on economic activity", by F. Altissimo, E. Georgiou, T. Sastre, M. T. Valderrama, G. Sterne, M. Stocker, M. Weth, K. Whelan, A. Willman, June 2005.

30 "Competitiveness and the export performance of the euro area", by a Task Force of the Monetary Policy Committee of the European System of Central Banks, June 2005. 
31 "Regional monetary integration in the member states of the Gulf Cooperation Council (GCC)" by M. Sturm and N. Siegfried, June 2005.

32 "Managing Financial Crises in Emerging Market Economies: Experience with the Involvement of Private Sector Creditors", by an International Relations Committee task force, July 2005

33 "Integration of securities market infrastructures in the euro area", by H. Schmiedel, A. Schönenberger, July 2005. 
